MA MAJOR RESEARCH PAPER

\title{
DOES MODERNIZING MEAN WESTERNIZING? \\ Western views of New China's Graphic Design \\ 1998-2008
}

CATHERINE JO ISHINO

\author{
MICHAEL PROKOPOW, SUPERVISOR \\ WENDY WONG, SECOND READER
}

The Major Research Paper is submitted in partial fulfillment of the requirements for the degree of Master of Arts

Joint Graduate Program in Communication \& Culture Ryerson University - York University

Toronto, Ontario, Canada

September 23, 2009 


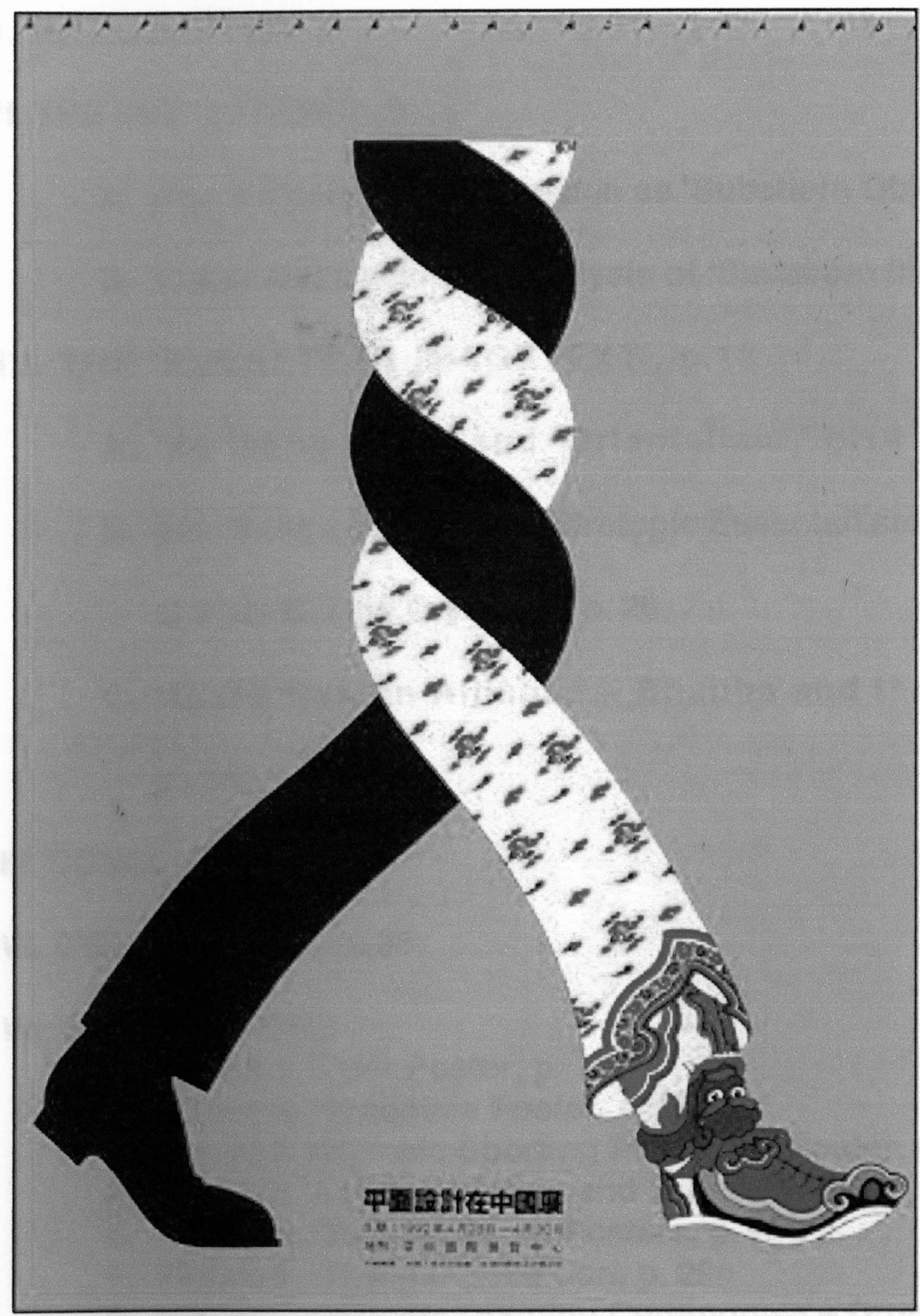

Poster for Graphic Design in China Exhibition, 1992

\author{
By Chen Shaohua
}


I. INTRODUCTION, p. 3

II. THE SUBALTERN, p. 6
A. New China's Graphic Design as 'Subaltern Object,' p. 8
B. Visual and Discourse Analysis of 'Subaltern Imagetext,' p.12

III. THE 'SUBALTERN IMAGETEXT', p.13
A. Xu Wang - Said and 'Orientalism,' p.14
B. Min Wang - Spivak and 'Strategic Essentailism,' p. 20

1) 2008 Beijing Olympics, p. 28

C. MEWE Design Alliance - Bhabha and the 'Third Space,' p. 31

III. CONCLUSION, p. 36

VI. BIBLIOGRAPHY, p. 38

VII. ILLUSTRATIONS
A. Figure 1, Tiger Poster, p. 16a
B. Figure 2, Hiroshima Poster, p. 18a
C. Figure 3, Olympic Sporting Pictogram Poster, p. 23a
D. Figure 4, Ancient Writing and Bronze Vessel, p. 23a
E. Figure 5, Olympic Event Posters, p. 25a
F. Figure 6, Olympic Coke Can, p. 29a
G. Figure 7, Olympic Opening Ceremonies - Drummers, p. 31a
H. Figure 8, Olympic Opening Ceremonies - Countdown, p. 31a
I. Figure 9, Olympic Opening Ceremonies - Fireworks, p. 31b
J. Figure 10, Shenzhen Poster, p. 35a 


\section{DOES MODERNIZING MEAN WESTERNIZING? \\ Western views of New China's Graphic Design,1998-2008 \\ By Catherine Jo Ishino}

Designers are visual ambassadors, creating vehicles of communication intended to carry messages within or across cultural barriers.

- Designing with Symbols for an International Market, Maggie Macnab, 2000 -

Orientalism ... had the merit of enlisting itself openly in the struggle, which continues... in 'West' and 'East' together. [...] .... neither the term Orient nor the concept of the West has any ontological stability; each [is] made up of human effort... it is incumbent upon us [the Eastern and Western hemispheres] to... dismantle the reductive formulae and the... potent kind of thought that leads the mind away from concrete human history and experience ...

- Edward Said -

In subaltern studies, because of the violence of imperialist epistemic, social, and disciplinary inscription, a project understood in essentialist terms must traffic in a radical textual practice of differences.

- Gayatri Spivak -

the theoretical recognition of the split-space of enunciation may open the way to conceptualizing an international culture, based not on the exoticism or multi-culturalism of the diversity of cultures, but on the inscription and articulation of culture's hybridity.

- Homi K. Bhabha -

\section{INTRODUCTION}

This paper seeks to describe the Western visual hegemonic discourse surrounding the graphic design of what is now called 'the New China' in the two decades prior to the 2008 Beijing Olympics, and the current global economic crisis. I will make the case before 2008 and the Peoples Republic of China's (PRC) triumphant Olympic Games, China's design was of being seen as a 
'subaltern visual object.' from the perspective of the Western design profession.

The latter's stance lags far behind the prevailing counter-hegemonic narratives of the long-standing postcolonialists' theories and theorists of the 1970s-1980s.

So in taking up the postcolonialists' counter-hegemonic narratives, I contend the Western designers' narrative of China was envisaged when the 'Occidental' hemisphere, perceived itself as reigning supreme over the 'Oriental' hemisphere, at a time when Euro-American capitalism was at its apex during the 19th and 20th centuries. The latter deemed their industrial and information revolutions as justifiable affirmations of their international imperialistic power. The Westernized hegemonic capitalism and image-driven consumer ethos became globally pervasive. However, following the visual tour de force of the 2008 Olympics and the West's dramatic economic instability in late 2008 , I believe the subordinate view of the New Chinese graphic design, held by the West, merits and requires a second look.

As an entry point, for this paper, informed as it is ahead by discourse and visual analysis, I will show how three major and classical postcolonial theories of the 'subaltern' can be attached to China's graphic design, pre-2008. Furthermore, I will argue for the subordinate term, 'subaltern', be re-evaluated and detached from this rising Eastern nation's 'imagetext." Lastly, this paper is speculative gesture, as I would like to test the viability in the academic arena of combining the premises of postcolonial theory to the underlying assumptions made in the

\footnotetext{
${ }^{1}$ Mitchell proclaims 'picture theory' and 'visual culture' is deemed as a subordinate in scholarly fields. The object of study - images or pictures - he therefore designates as 'subaltern imagetext'.
} 
Western graphic design profession. Please take note that 'design writing criticism' is in its beginning stages as a scholarly endeavor and just starting to be taught at the post-graduate level in North America and Great Britain. In 2008, the first graduate-level Master of Fine Art in Design Criticism was offered in the USA, at the School of Visual Arts in New York City. The chair, Alice Twenlow, announced:

Public awareness of design and its social, economic, and even political implications is growing. With this new program we aim to build design criticism as a discipline and contribute to public discourse with new writing and thinking that is imaginative, historically informed, and socially accountable. $^{2}$

Also in 2008, the London College of Communications (LCC) at the University of the Art London opened up its first Masters level degree in Design Writing Criticism, stating it was "the first course of its kind in Europe." ${ }^{3}$ They described the program as a place where graduate students will "explore the impact of writing and criticism on contemporary design thinking and practice." In a 2007 "Blueprint" magazine article, co-founder of the new LCC MA, Teal Triggs states:

Design has long been the poor relations of other forms of critique. ...the development of a new MA course in Design Writing/Criticism... is one of the first courses of its kind... Design writing and criticism has not been formally recognised as a vital component of design education. ${ }^{4}$

So given the newness of the design writing criticism discipline in academia

\footnotetext{
${ }^{2}$ http://www.schoolofvisualarts.edu/news/index.jsp?content_id=1835\&page_id=519\&sid0 $=228$ (accessed September 19, 2009).

${ }^{3}$ http://www.Icc.arts.ac.uk/courses/postgraduate/design_writing_criticism.htm\# (accessed September 19, 2009).

${ }^{4}$ www.lcc.arts.ac.uk/docs/080_BLUEPRINT_OCTOBER.pdf (accessed September 19, 2009).
} 
(not to mention the term, 'graphic designer' was just coined by American William Addison Dwiggins, less than 100 years ago, in $\left.1922^{5}\right)$, I find myself exploring uncharted territory. However in doing so, I will link postcolonial theory of the subaltern to how the Western graphic design profession has viewed the 'New China' graphic design in the past two decades, from 1998 to 2008. Lastly, I will accomplish this by connecting examples of the work of three Chinese designers' works to three postcolonialists' theories and theorists.

\section{THE SUBALTERN IMAGETEXT}

W. J. T. Mitchell, visual culturalist, claimed in 2004, the "image is like the politically oppressed 'other', a subaltern subject that has not been allowed to speak in academia,"' ${ }^{\prime \prime}$ and where the 'written word' is reified over the 'subaltern imagetext'. (NOTE: I will adopt Mitchell's term, from here on out, to denote both the postcolonial notion of the 'subaltern object' and his poststructural idea of 'imagetext'.) Gayatri Spivak, feminist post-colonialist, stated in 1992, the 'subaltern' is not “...just a classy word for oppressed, for Other, for somebody who's not getting a piece of the pie.... In postcolonial terms, everything that has limited or no access to the cultural imperialism is subaltern - a space of difference." However, it was Antonio Gramsci, the Italian Marxist, who is credited

\footnotetext{
${ }^{5}$ Alan Livingston and Isabella Livingston, Dictionary Of Graphic Design And Designers, (London: Thames and Hudson), 1992.

${ }^{6}$ WJT Mitchell. Afterimage, (Jan/Feb 2006): 49.

${ }^{7}$ Leon de Kock. "Interview With Gayatri Chakravorty Spivak: New Nation Writers

Conference in South Africa", A Review of International English Literature, 23(3), (1992):

29-47.
} 
with appropriating the word 'subaltern' in $1926,{ }^{8}$ to designate the underclass, while writing his "Prison Notebooks: 1926-1934." During his imprisonment, Gramsci also developed his theory of 'cultural hegemony.' He believed in the $20^{\text {th }}$ century, if any one class was to move beyond its own economic self-interests and benefits, it must construct its own cultural forms, intellectual ideas, and moral leadership. In this way, they could gain the most pervasive and unrivaled control, as well as power, over any other class. Later social thinkers would build upon Gramsci's concepts, like postcolonialist Edward Said. In 1978, the latter stated the 'Occident' had indeed captured a hegemonic cultural control over the 'Orient' in the late $19^{\text {th }}$ and early $20^{\text {th }}$ centuries, writing:

certain cultural forms predominate over others, just as certain ideas are more influential than others; the form of this cultural leadership is what Gramsci has identified as hegemony, an indispensable concept for any understanding of cultural life in the industrial West. It is ...the result of cultural hegemony at work, that gives Orientalism the durability and the strength... indeed it can be argued that the major component in European culture...the idea of European identity as a superior one in comparison with all the non-European peoples and cultures. ${ }^{10}$

To reiterate, it is Gramsci's notion of the 'subaltern' and 'cultural hegemony,' as seen from Said's 'postcolonial turn' in his conceptualization of his binary 'Occident' and 'Orient,' where I will begin my entryway into describing

\footnotetext{
${ }^{8}$ The dictionary places the term's beginnings in the $16^{\text {th }}$ century, translated in Late Latin as subalternus, or sub- 'below' and alternus 'every other'. The noun, subaltern, was used to describe a subordinate ranking below the standing of a captain in the British military, but its usage was discontinued by the late $18^{\text {th }}$ century. http://dictionary.reference.com/wordoftheday/archive/2003/01/06.html (accessed August 17, 2009).

${ }^{9}$ He was imprisoned during the Mussolini dictatorship for his anti-tolatarian ideas

${ }^{10}$ Edward Said, "Introduction", Orientalism, (London: Penguin Books), 2003 [1 ${ }^{\text {st }}$ ed.1978], 7.
} 
through visual and discourse analysis about the 'New China' graphic design as a 'subaltern imagetext,' at least, in the eyes of the Western design profession from 1998 to 2008.

\section{A. New China's Graphic Design as 'Subaltern Imagetext'}

A positive view on the state of modern Chinese graphic design was difficult to find in the Western professional design press, until most recently, after the 2008 Beijing Olympic games took place. From the time, the Chinese Communist government reorganized in the early 1980 s through the 1990 s and in the early days of the New China's free market economy, American trade journals reporting on graphic design being produced in China portrayed the country's works as derivative and imitative of Western practice. Noted design historian, Victor Margolin explains this misunderstanding, in his review of Scott Minick and Jiao Ping's book, Chinese Graphic Design in the $20^{\text {th }}$ Century.${ }^{11}$ Margolin found out in reviewing the text, how Chinese differ from Western designers in adopting new design styles. Margolin writes, in the West 'new-ness' bases its continuum of change as "representations of the dominant ideology of cultural modernity."12 However this form of Western modernism, he reveals, in China is seen as extreme and outside their own culture, where tradition and history are revered as

${ }^{11}$ Design Issues, Vol. 8, No. 2, (Spring, 1992): 82-84.

${ }^{12}$ Ibid.: 82. 
well as followed for centuries. In Minick and Ping's book, ${ }^{13}$ Margolin reviews how they trace 'indigenous design' back to the first century A.D., when the Chinese invented papermaking. Furthermore, Margolin notes not until the $12^{\text {th }}$ century was the West even capable of re-creating this technology. Given Chinese wood block printing began in 868 A.D. and moveable type was used between 1041-1048, China historically begins designing books 400 years ahead of Gutenberg and his famous bible, which was first printed circa 1439. The first Chinese printed books were discovered beginning in 636 A.D. In short, the practice of design is not a recent Western import to China, rather a long-standing historic practice by these three design historians' learned judgments.

To the contrary, design writer and educator, Clive Dilnot, in his 2003 Design Issues article, "Which Way Will the Dragon Turn?"14 writes about the Euro-American corporations entering British Hong Kong and later Mainland China. Dilnot ${ }^{15}$ maintains the Westerners brought in their own art directors and creatives to oversee the local designers' work output. Once the locals were hired, they did not have the luxury of time to innovate their own design work - it was enough to contend with learning new technologies, grappling with the imported visual language, and still meet the foreigners' unyielding deadlines. The entrepreneurs' goal in hiring these New Chinese designers was to get the most

\footnotetext{
${ }^{13}$ Scott Minick and Jiao Ping, Chinese Graphic Design in the Twentieth Century. (London: Thames and Hudson), 1990.

${ }^{14}$ Clive Dilnot, "Which Way Will The Dragon Turn? Three Scenarios For Design In China Over The Next Half-Century." In Design Issues, Vol. 19, No. 3, (Summer 2003): 5-20.

${ }^{15}$ Dilnot taught at the Hong Kong Polytechnic University from 1995 to 2000.
} 
output, at the lowest cost, and in the quickest amount of time. Then these venture capitalists would export the goods and sell them at a higher profit margin to their Western consumers, who in turn, were looking for the best prices their money could purchase. Replicating, rather than creating, clearly was the most cost efficient in this profit-making dynamic. Thus the local Chinese designers were given the task of copying works for the sake of efficiency. ${ }^{16}$ Dilnot summarizes his Western perspective on the New Chinese design in this way:

'R\&D' means not research and development but replication and duplication. The negative implications for design epitomized by this model are obvious - the copy economy always will tend to trivialize, cheapen and operationalize the role of the designer. But is this situation all bad? Certainly it indicates the objective, structural, difficulty of establishing a mature design profession in China today, if by mature profession we think of something on the model of American or western European practice. But is this really what is required? Is there perhaps within the emerging situation, especially in the longer term, the seedbed of a different model of design altogether? ${ }^{17}$

Dllnot goes on to point out the different ways in which the Chinese designers could take their work in another direction. Of primary importance, he argues, "if the country were to move from being a 'low-cost manufacturing unit' to being the global center of new product innovation' this act would be the most transformative and empowering."18

Five years after Dilnot's publication, in 2008, the Victoria \& Albert Museum

\footnotetext{
${ }^{16}$ For more information see: Shou Zhi Wang, "Chinese Modern Design: A Retrospective" and "Design in Asia and Australia," Design Issues, Vol. 6, No. 1, Autumn, 1989, 66-68. ${ }^{17}$ Clive Dilnot, "Which Way will the Dragon Turn? Three scenarios for design in China over the next half-century," In Design Issues, Vol. 19, No. 3, (Summer 2003): 5-20,12. 18 Ibid: 14.
} 
in London mounted a blockbuster exhibit, called China Design Now. ${ }^{19}$ On display were over 200 projects from Shanghai, Shenzhen, and Beijing. the three major burgeoning and most industrialized cities in China. The design works covered the period from when the Country's switched full force to a 'free market economy' in the early 1990 s to early 2000 s. Unfortunately even in 2008 , there remains evidence of European hegemony still lingering on. The London Times' newspaper critic, Tom Dyckhoff, wrote his review of the China Design Now exhibition:

unveiling the material magnificence of another [besides Japan] longisolated, mysterious, oriental civilisation, but one, which is now suddenly ubiquitous. ... What is dispiriting is not just that China's entire design output seems solely defined by rabid capitalism. It is how familiar are the products of this mysterious, oriental civilisation. ${ }^{20}$

Indeed even some of the pages from the China Design Now catalog, asks these hegemonic questions:

The speed of social change in contemporary China is a constant influence on this generation [of up and coming graphic designers]. How can one derive inspiration from a rapidly changing reality? Can those cheap Chinese textiles and plastic products the socialist way of life and socialist habits be transformed into a design language with distinctive Chinese features? ${ }^{21}$

\footnotetext{
${ }^{19}$ For the exhibition itself, see: http://www.vam.ac.uk/vastatic/microsites/1636 chinadesignnow/(accessed April 2008). 20 Tom Dyckhoff. "China Design Now at the Victoria \& Albert Museum." March 14, 2008.

http://entertainment.timesonline.co.uk/tol/arts_and_entertainment/visual_arts/architectur e_and_design/article3549114.ece. (accessed August 2009).

For the exhibition itself, see:

http://www.vam.ac.uk/vastatic/microsites/1636 chinadesignnow/ (accessed April 2008).

${ }^{21}$ Ye Ying, "Get It Louder," edited by Zhang Hongxing and Lauren Parker, China Design Now, (London: V \& Publishing), 2008, 66.
} 
Ironically, the most positive outcome of the popular exhibition was breaking down the entrenched Western culture and pre-existing hegemonic barriers more, because the high profile design show was shown at a long-held British establishment as London's Victoria Albert Museum (1852). The V\&A is known to hold the largest decorative arts and design collection in the world, and one the biggest East Asian collections, comparable to New York's Metropolitan Museum of Art and Paris' Musee du Louvre.

\section{B. Visual and Discourse Analysis of Subaltern Imagetext}

In the context of the postcolonial sublalternity, can the 'New China' graphic design be seen as 'Chinese Modern' design, ${ }^{22}$ that is, beyond its subordinate position designated by Euro-American hegemonic design professionals? Can the Western designers see the 'Chinese Modern' graphic design as an entity unto itself, or merely as a bad imitation of the West's own work? Does the 'modernization' of the 'New China' graphic design necessitate that it 'Westernize'? Or is this question narcissistic and hegemonic as Margolin alluded to earlier - that in the West 'new-ness' bases its continuum of change as "representations of the dominant ideology of cultural modernity?"23

For all intents and purposes of this short paper, I suggest the answers to these questions lie beyond Gramsci's 'cultural hegemony,' or Said's binary of

\footnotetext{
${ }^{22}$ My thanks to Chinese design expert and my second reader, Wendy Wong, for making me aware of the term, 'Chinese Modern.'

${ }^{23}$ Ye Ying, "Get It Louder," edited by Zhang Hongxing and Lauren Parker, China Design Now, (London: V \& Publishing), 2008, 82.
} 
'Orient' and 'Occident,' or Spivak's 'strategized essentialism,' and resides more with post-colonialist and post-structuralist Homi K. Bhahba and his conceptualization of a 'Third Space' constituted of cultural 'hybridity' and 'multivocality.' Therefore, I will survey and describe succinctly, through visual and discourse analysis, three different Chinese graphic designers' works - Xu Wang, Min Wang, and He Jun - then contexturalize each one as representative of Said, Spivak, and Bhabha varying subaltern and postcolonial positions.

\section{THE SUBALTERN IMAGETEXT}

Until the advent of post-colonialism, the forces of the Western Empires continued to define non-Western cultures as the 'Subaltern.' In the 1978 edition of Orientalism, Said emphasized "neither the term Orient nor the concept of the West has any ontological stability; each [is] made up of human effort... these supreme fictions lend themselves easily to manipulation and the organization of collective passion..." ${ }^{24}$ In addition, he advocated "it is incumbent upon us [the Eastern and Western hemispheres] to... dismantle the reductive formulae and ...potent kind of thought that leads the mind away from concrete human history and experience $\ldots{ }^{25}$ what has really been lost is a sense of the density and interdependence of human life." ${ }^{26}$ Lastly, in his 1994 edition of the same book, in its "Afterword," Said ruminates, "Looking back [16 years later]... the availability

\footnotetext{
${ }^{24}$ Edward Said, Orientalism, (London: Penguin Books), 2003, [first edition 1978], xvii.

${ }^{25}$ Ibid., xxiii.

${ }^{26}$ Ibid., xxvii.
} 
of a massive new interpretive and scholarly enterprise to reduce the effects of imperialist shackles on thought and human relations, Orientalism ... had the merit of enlisting itself openly in the struggle, which continues... in 'West' and 'East' together." ${ }^{27}$

\section{A. Xu Wang - Said and 'Orientalism'}

The contemporary Chinese designer that best exemplifies Said's position of historical mutability is Xu Wang. Like Said, Wang believes rather than adhering to a fixed conception of the Eastern and Western graphic design, both can change. Most known in the West of Mainland Chinese designers, Xu Wang, stands out prominently. In 1998, he was nicknamed 'Graphic Design's Evangelist in China' by Europe's main design magazine, Graphis. ${ }^{28}$ This title was bestowed upon him, as he is widely known for traveling to the West to show what is currently being done in the Peoples Republic of China's (PRC) design profession. Wang frequently gives lecture tours, distributing his design books and magazines containing the best of contemporary PRC work throughout Europe and the USA. ${ }^{29}$ Also Wang continues to do his own work, primarily for art and museum venues, and participates in the highly popular and competitive 'Regional Thematic Poster

\footnotetext{
${ }^{27}$ Ibid., 352.

${ }^{28}$ Chris Anderson, "Wang Xu: graphic design's evangelist in China," Graphis 316, (1998): 22-31. For more on design writer's resume see: http://lib.colostate.edu/posters/results-artists.php?id=345. (accessed June 2007). ${ }^{29}$ I saw Xu Wang when he presented at the Alliance Graphique Internationale (AGI) annual conference in San Francisco, 2002. At the time he presented the work and video interviews of designers from all around China.
} 
Invitationals' that begun in the late $1990 \mathrm{~s} .{ }^{30}$ His avid energy and work is felt throughout the global design community.

Between 1985 and 1992, Xu Wang lived and worked in British Hong Kong, then returned to his hometown of Guangzhou, where he began his own design studio and publishing company. In 1994, he started his self-published, EnglishChinese bilingual graphic design magazine, called the Design Exchange. Quickly the publication proved to be "the most influential and widely circulated graphic design magazine in all of China, ${ }^{31}$ especially with added commercial and financial backing of various companies.

In 1993, for Print magazine, ${ }^{32}$ Min Wang and his wife, Xiao Hong Shen, a cross-cultural studies scholar, ${ }^{33}$ wrote an article, called "After Mao: Chinese Graphic Design Today." ${ }^{34}$ The article highlighted Xu Wang's work. The couple had decided to return back to their homeland of the PRC for a visit, after living in the USA since the early 1980 s. While there, they went for a design tour of the provinces. In their writing, they revealed what they found in their travels and explorations. Min Wang and Xiao Hong Shen saw Xu Wang's work as most fully integrating Euro-American and Chinese cultures given the wide range of

\footnotetext{
${ }^{30}$ Wendy S. Wong, "Detachment and Unification: A Chinese graphic design history in Greater China since 1979." Design Issues, Vol. 17(4), p. 51-71, (Autumn 2001): 66.

${ }^{31}$ Min Wang and Xiao Hong Shen. "After Mao: Chinese Graphic Design Today." Print 48.n3, (May-June 1994): 64- 68.

${ }^{32}$ This is an industry trade magazine to which US designers often subscribe.

${ }^{33}$ Shen was educated at Yale in American Studies and Stanford got her PhD in China US relations. Min Wang is a Yale MFA design graduate and was project manager for Adobe, a graphics software developer and manufacturer.

${ }^{34}$ Min Wang and Xiao Hong Shen. "After Mao: Chinese Graphic Design Today." Print 48.n3, (May-June 1994): 64- 68.
} 
designers they met and interviewed. As Min Wang and Shen pointed out, though Xu Wang's major emphasis was on visual elements that will cross cultures, his perspective remained Chinese. The writers felt his work fused Chinese and Western design conceptions and manifestations the best. In finishing up their extensive survey of PRC designers, the authors respectfully gave Wang the last word, in which he declared, "to have our own identity and to improve our design by gaining nourishment from our rich Chinese culture and traditions is a challenge for us all."

Xu Wang further exemplified his cross-cultural abilities in an annual poster he designed for a Chinese commercial paper production company and audience. He played with the notion of representing the Chinese zodiac, which at the time was the Year of the Tiger (see fig. 1). The elements of this poster ingeniously are conceived to suggest a second reality of a calendar and to create a graphical concept to announce the Year of the Tiger..$^{35}$ The yellow and black stripes of the tiger's tail are made up and display the 12 months of the Western calendar year. The body of the animal is positioned in a Western-style design trope with the legs and head of the Tiger intentionally left out of the picture frame, leaving the viewer's mind's eye to fill in the missing parts. ${ }^{36}$ Xu Wang's layout intentionally breaks with classical Chinese scroll painting, where traditionally the entire object of focus would be depicted in its entirety, except of course for background of the

\footnotetext{
${ }^{35}$ Designer: Wang Xu, Client: Guangdong Fu Tak Fine Paper Co Ltd.

${ }^{36}$ This way of framing imagery was derived from Gestalt psychology. The visual expectation is the viewer will 'fill in' the total picture, being familiar the how the image looks in its entirety.
} 


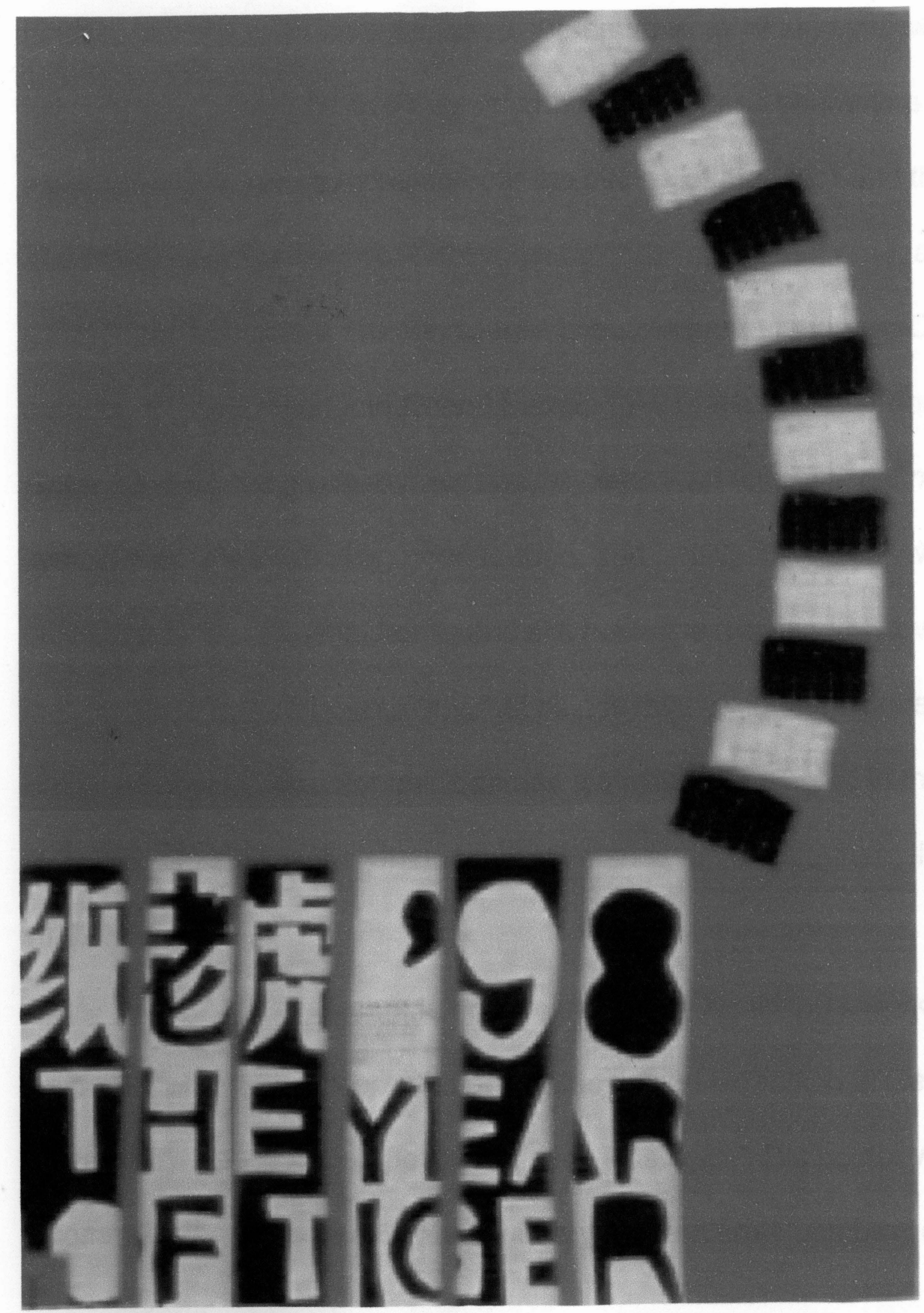

Fig. 1 Year of the Tiger, Xu Wang, 1993 
landscape setting. In the latter case, the entire body of the tiger would have been fully depicted. The type is constructed both in Chinese characters and the Roman alphabet in English, comprising both the stripes of the Tiger and the poster's title. The colors, Wang chose for his overall calendar's color scheme, are red and gold. These two colors are considered to be the luckiest hues in China. As authors, L.K. Peterson and Cheryl Dangel Cullen, write in their book, Global Graphics: Color, A guide to design with color for an international market, ${ }^{37}$ red symbolizes "good luck, joy, good fortune, and fertility." ${ }^{38}$ The yellow originally was only used by the Imperial family and still holds the meaning of power and royalty in it. Yellow also symbolizes "joy, happiness, high spirits and sunshine" ${ }^{39}$ much like in the West. The color black carries a similar meaning as in the West, but more specifically, for the Chinese, black stands for "depth, truth, life and stability." ${ }^{\prime \prime 0}$

In 2005, twelve years later, the maturity of Xu Wang's work can be seen in his poster entry to an international graphic design exhibition in Germany named, "Pictorial Writing - Contemporary Chinese Posters." ${ }^{41}$ His poster was designed as a commemoration for the $60^{\text {th }}$ anniversary of the atomic bombing of Hiroshima

\footnotetext{
${ }^{37}$ L.K. Peterson and Cheryl Dangel Cullen, "The Asian Pacific Rim," 146-179. Global Graphics: Color, A guide to design with color for an international market, (Gloucester, MA: Routledge), 2000, 148.

38 Ibid., 148.

${ }^{39}$ Ibid., 148.

40 Ibid., 148.

${ }^{41}$ This web exhibition accompanies the exhibition at the Hochschule fuer Gestaltung und Kunst, Roessligasse 12, Lucerne (Switzerland) from September 14 to November 6, 2005, curated by Jianping He and Urs Straehl. http://www.posterpage.ch/exhib/ex135typ/ex135typ.htm (accessed September 2006).
} 
and Nagasaki. Wang created the posters as a non-commercial piece of work, exclusively for this design showing in this international venue. This poster we now can see him fulfilling his own earlier Chinese design challenge that he had set out for himself (see fig. 2). On the left, Wang fore-fronts his Eastern design sensibilities and culture, with a Western design hint now appearing secondary in his work. For the purposes of this brief paper, I will focus only on his Hiroshima poster on the left hand side of the page. His bold, black calligraphic characters are painted with vigor and confidence. A Chinese viewer would be able to see in Wang's calligraphy that some parts of the strokes, which comprise the name of the city, are missing. So for those able to read Chinese, the sporadic paint strokes could conjure up the image of Hiroshima transmuted and blown apart with the city's buildings falling apart and her people vaporized. In fact, one Asian reviewer of the poster exhibition noted in Xu Wang's poster, the designer intentionally treated the Chinese calligraphy in a visual manner that would evoke the absence of Hiroshima's people for their $60^{\text {th }}$ year commemoration. Furthermore, the bold black paint strokes deconstructing from the upper right hand side to the lower left bottom create a double entendre for either Easterner or Westerner - symbolizing both the human bones cascading downward as well as the 'black rain' or nuclear fallout seen at ground zero. Also, given calligraphy is one of the highest art form in China and is much appreciated in the West, $\mathrm{Xu}$ Wang reveals his own artistic bravado here as well. The confidence of his 

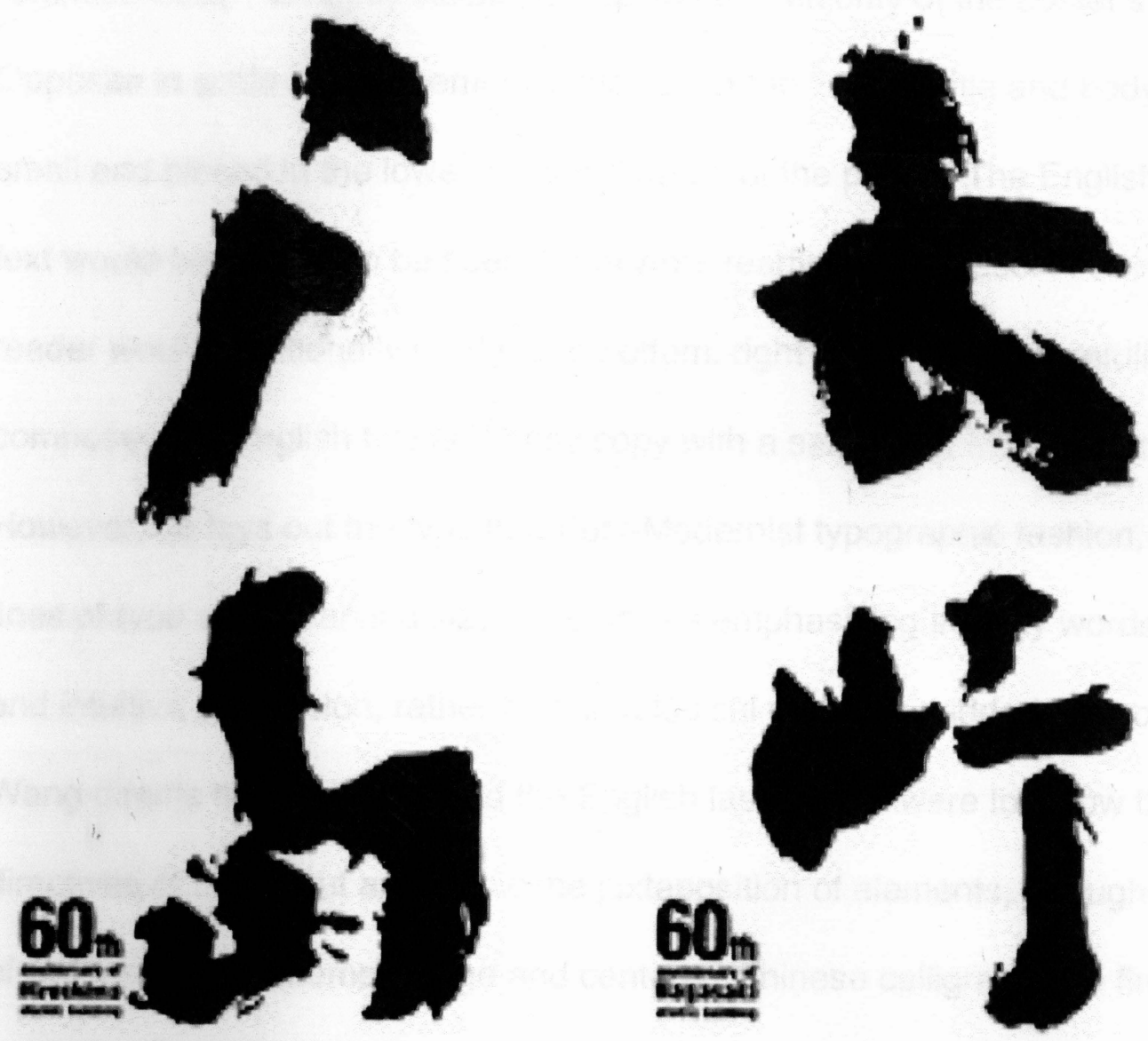

Fig. 2 Xu Wang's Poster of Hiroshima and Nagasaki 
'Chinese-ness' ${ }^{\prime 2}$ is highly visible, occupying the majority of the poster's space. Opposite in scale and placement is his use of the English title and body text so small and placed in the lower left-hand frame of the poster. The English writing or text would be the last to be seen if one were reading in Chinese. A Chinese reader would traditionally read top to bottom, right to left. Wang carefully composes the English title and body copy with a sans serif, Modernist typeface. However, he lays out the type in a Post-Modernist typographic fashion, so the lines of type are of varying sizes and scales emphasizing the key words in felt and intuitive expression, rather than in a logical or tightly gridded method. Xu Wang directs the viewer to read the English last - if one were to follow the directives of his layout and follow the juxtaposition of elements, through his use of scaling, from extremely large and centered Chinese calligraphy he finally moves to the small off-centered, lower left English text placed in the corner. Nonetheless in the English body copy and the 'imagetext' - '60th' and the name of the city of 'Hiroshima' - are enlarged for emphasis, ease of reading, and to clarify to his Western audience what the poster might be depicting. Wang must have been fully aware as a designer that his viewing audience would be Europeans, given the show was being held in Germany. He also must have used the English text, knowing the language is the most widely used and understood among an international audience. Other 'imagetexts' to note are the background

\footnotetext{
${ }^{42}$ Wendy Wong, "In Search of a New Graphic Design Frontier in China: Establishing the 'Chinese-ness' of International Style," Journal of the Asian Design International Conference, Vol. 1, 2003. http://design.yorku.ca/research/wwong.php (accessed August 2008).
} 
color of white, it is a symbol for 'death and mourning' in Asia and there is "an overabundance of white space around ... an isolated... lettering might [also] hint at funerary meanings. ${ }^{133}$ Beyond my earlier description of the use of the color black in Chinese visual communication in Wang's "Year of the Tiger" calendar poster, black also may represent "mystery and even danger" in the Hiroshima poster. Xu Wang's ideal of Chinese graphic design operating in a contemporary international design context, as well as retaining his own cultural identity and visual voice has been fulfilled in this poster design. The latter work also stands out clearly from his earlier 1993 work in the "Print" magazine article.

Thus, Xu Wang's two posters visibly demonstrate and reinforce Said's position of a mutable history. Clearly the designer has shifted the balance of China's 'subaltern imagetext' to a new level of respect. His poster can be seen as is deeply Chinese, yet also contains English design elements. Xu Wang has begun to create in this work, a new synthetic and visual language that contains neither 'Orient' and 'Occident,' rather as Edward Said predicted, one in which we see ourselves in a world transformed.

\section{B. Min Wang - Spivak and 'Strategic Essentailism'}

Theorist Gayatri Spivak argues for "strategic essentialism" in subaltern postcolonial studies. She maintains, in order to create a conversation in opposition to the dominant colonial power, postcolonialists may have to position

${ }^{43}$ L.K. Peterson and Cheryl Dangel Cullen, "The Asian Pacific Rim." Global Graphics: Color, A guide to design with color for an international market, (Gloucester, MA:

Routledge), 2000, 146-179. 
themselves as the 'other.' As a matter of strategy, this first stance of essentializing one's own identity may be necessary, so as to begin from a place that challenges and changes the dialogue of the colonized to the colonialist. As Spivak writes: "In subaltern studies, because of the violence of imperialist epistemic, social, and disciplinary inscription, a project understood in essentialist terms must traffic in a radical textual practice of differences." ${ }^{44}$ Her concept would be to sever the binary that Said so well defined in his Orientalism theory, namely the 'Occident' created the 'Orient,' to justify their colonization and to define as well as rationalize the former's behavior and existence. Spivak intoned: "Some of the most radical criticism coming out of the West today is the result of a interested desire to conserve the subject of the West, or the West as Subject. ...the history of Europe as Subject is narrativized by the law, political economy, and the ideology of the West, this concealed Subject pretends it has 'no geopolitical determinations." ${ }^{45}$ In Spivak's postcolonial project, the end goal would be not to be seen nor defined as the "subaltern object," rather in a manner of the postcolonialists' own choosing, that is how they would like to define and see themselves, and not in relationship to the colonialists. The latter step once taken, would move the colonized, or the 'subaltern object,' from having to be 'strategic essentialists,' that act in defiance of the dominant colonial power. In other words, in the process of posturing, they would find their authentic voice, and not just

\footnotetext{
44 "Can the Subaltern Speak?," in The Postcolonial Reader, edited by Bill Ashcroft and Gareth Griffiths, Helen Tiffin, (New York: Routledge), 1997, 27.

${ }^{45}$ Ibid., 24.
} 
reactionary one of 'speaking truth to power.' They would newly articulate and voice the postcolonialists' self-defined reality with clarity and strength.

I believe Spivak's ideological cultural desire is one shared by Bejing Olympic design director, Min Wang. He wrote in 2001, even before he knew he would become the design director of the 2008 Games:

Our modernization path should be characterized by synthesis, innovation and sustainable development... We should find our own way based on our own culture and tradition. ... we need to proactively retain and promote our heritage and be cautious against indiscriminately copying western design theories or design languages. ${ }^{46}$

While Wang was coming of age (b. 1956), when Beijing entered onto the global stage during the Communist government's Four Modernizations Policy ${ }^{47}$ in 1978, then its Open Door Policy in 1979. By the year 2001, China had entered into the World Trade Organization (WTO). The same year, they also won the bid for the 2008 Olympics to be held in Beijing, an endeavor in which Wang participated. The English design press coverage of Chinese-born, American educated and trained designer, Min Wang, ${ }^{48}$ is featured prominently when he became the PRC's Design Director for the 2008 Beijing Olympics, and also when he was given the post as the Dean of the School of Design in the Chinese Academy of Fine Arts (CAFA), the PRC's only government-run art school.

\footnotetext{
${ }^{46}$ Min Wang, Square Two World, Square Two Design, TWO WORLD DESIGN, (Publication date not available, @ 2001),14.

${ }^{47}$ Deng Xiaoping pushes an era of reform concentrating on the advancement of China's agriculture, industry, science, technology, and national defense.

${ }^{48}$ Wang received his post-baccalaureate graphic design degrees in Germany and at Yale University. He also worked for Adobe Systems, Inc. for many years as Art Director then Project Manager. Wang devised the first Chinese character fonts for Japanese usage in the Adobe software Illustrator.
} 
Actually, I have found Min Wang to be the man of the most nuanced insight because he is so central to what is going on inside of China's design world today. This is due, I believe, to his bicultural background. He was born and came of age in China, during its transitional cultural and economic period. Also Min Wang sought further higher education abroad - in the Soviet Union's East Germany and later at Yale University. Then he lectured in the latter's university's graduate design program from 1989 to 1997 . Still later, Wang worked in the United States at Adobe, the software developer and manufacturing giant. His last position in the USA, was when he joined the studio of Square Two Design in San Francisco. This is also where he created his visual presentation for the 2001 PRC bid to hold the Olympics. Also, Wang speaks, reads and writes fluently in Chinese and English. As a student, designer and an academic, Wang was trained in a Bauhaus-based Modernist design methodology ${ }^{49}$ It is clear Wang holds the background to combine and create a unique cultural as well as social insight, to see and resolve tensions between Eastern and Western design sensibilities today.

In his poster design that depicts all thirty-four of the Olympic sporting events, Min Wang synthesized the modern and the traditional (see fig. 3). Innovating from the original and widespread usage of the 'Dancing Man' logo, which is the central image of the 2008 Olympics, Min Wang, innovates a grand

\footnotetext{
${ }^{49}$ From Min Wang's self-published book, Square Two World, Square Two Design: TWOWORLD DESIGN. (no publication date @2001).
} 


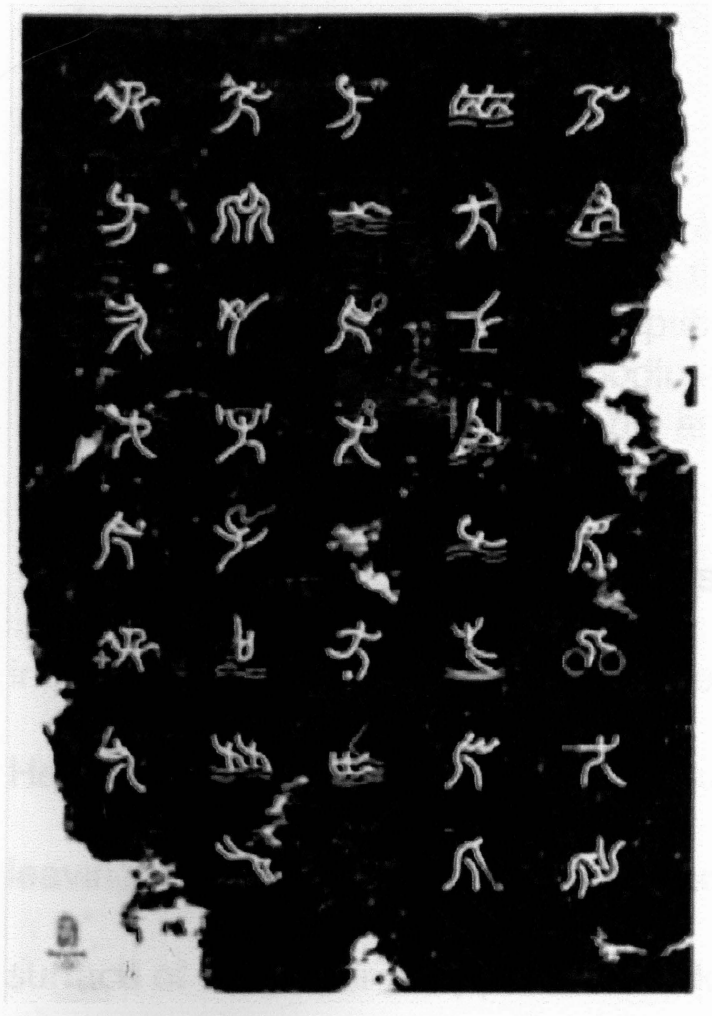

Fig. 3 Min Wang's 2008 Sporting Olympic Poster

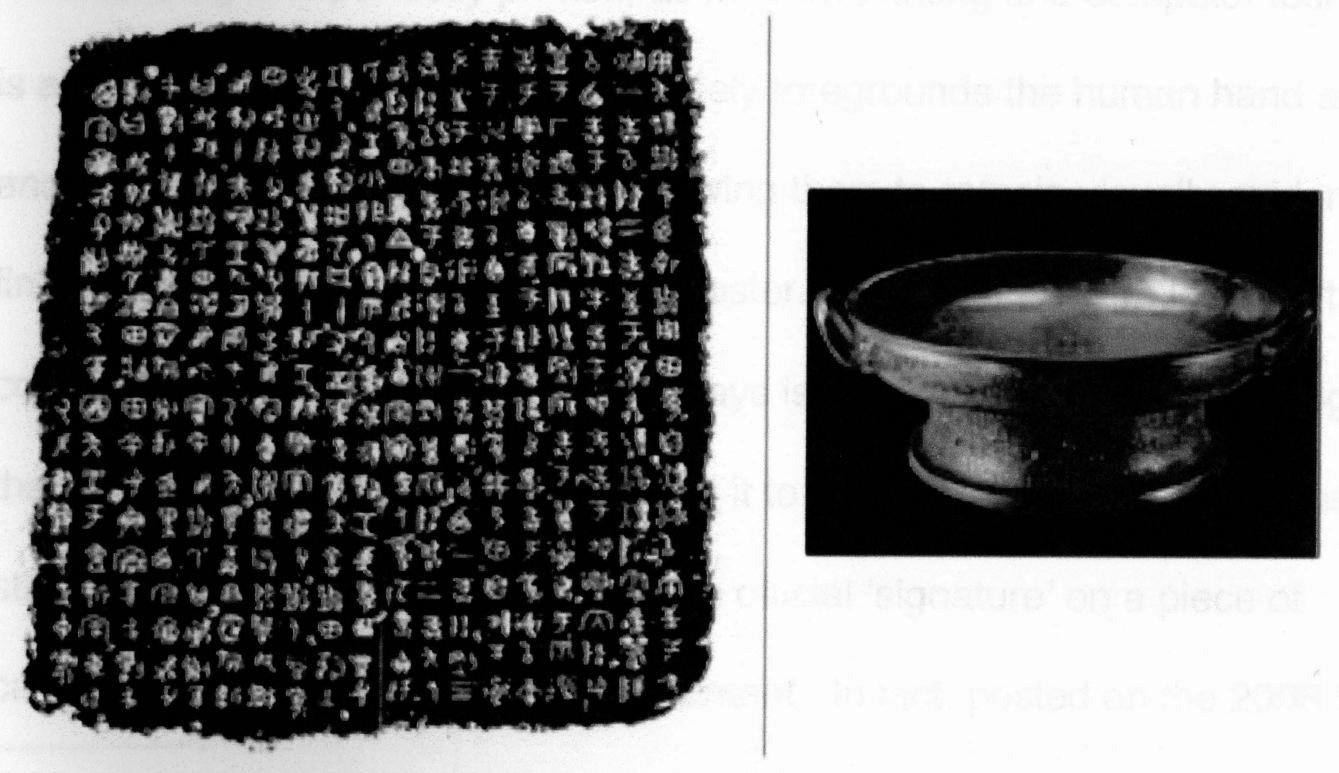

Figure 4 : Ancient writing style and bronze vessel 
metaphor reminiscent of an early Chinese printing technique. As the official 2008 Beijing Olympic website states:

the beauty of seal characters' and with strokes of seal characters as their basic form, the Pictograms of the Beijing 2008 Olympic Games integrate pictographic charm of inscriptions on bones and bronze objects in ancient China with simplified embodiment of modern graphics, making them recognizable, rememberable and easy to use..$^{50}$

Wang graphically simulates this ancient printing technique by giving the impression the Olympic sporting figures have been created in a similar manner. He leaves the edges of the black background paper appearing handmade by leaving the edges ragged, not clean and machine cut. Also he simulates the surface of the paper to appear as if inked on by hand, by allowing the white of the background surface to bleed through the inky black surface. Wang's graphic approach is not to have the poster's Olympic sporting figures appear mechanically and perfectly printed, as modern printing and computer technology is able to achieve, rather Wang purposely foregrounds the human hand and the ancient rubbing printing technique allowing them to remain visually evident in his final version of the sports pictograms poster. Additionally, in the lower-left hand corner, the image he symbolically displays is the 2008 Beijing Olympic logo of the 'Dancing Man,' but this time utilizing it to connotate a red-inked Chinese stamp or 'chop', that is often used as an official 'signature' on a piece of calligraphy or painting or a formal document. In fact, posted on the 2008 Beijing

50 "Pictograms of the Beijing 2008 Olympic Games unveiled." http://en.beijing2008.cn/37/34/article212033437.shtml (accessed January 2007). 
Olympic website is a visual mission statement of the overall image concept for branding the Game, which Wang seemed to follow closely:

The project of the Beijing 2008 Olympic Games Image and Look aims at creating unique, complete and consistent visual images... through architectural development and integrated application and management of the image elements... which include the Olympic Symbol, Beijing Olympic Games emblem, its color system, theme slogan, secondary marks, mascots, Olympic Pictogram, core patterns and a set of photographic images. ... the image elements of the Beijing Olympic Games, whose design...symbolize the Olympic Spirit and the concepts of this edition of the Olympic Games... They are the carrier to showcase to the world the culture and tradition, as well as the city images and human spirit of China and Beijing. They constitute significant wealth of the Beijing 2008 Olympic Games. ${ }^{51}$

What follows here are two more examples of Wang to demonstrate the flexibility and coherence of his branding and information design of the 2008 Olympics at work (see figs. 5). ${ }^{52}$ Wang transfers the original thirty-four pictograms into grey monochromatic backgrounds, so each individual sporting competition has its own representative poster. The original pictograms are now depicted out-of-focus and are made to be faint back-up imagery. However, they also display and possess more movement as well as fluidity. In moving his original foreground elements of the sporting pictograms poster into the background, Wang is able to highlight and foreground the color photographs of each individual sportsman performing in each event. Now each high resolution color photograph visually contrasts to the monochromatic grey backgrounds, and

51 "OLYMPIC Design System" http://en.beijing2008.cn/spirit/beijing2008/ (accessed September 2009).

${ }^{52} \mathrm{http} / / /$ en.beijing2008.cn/spirit/beijing2008/officialposters/sportsposters/ 


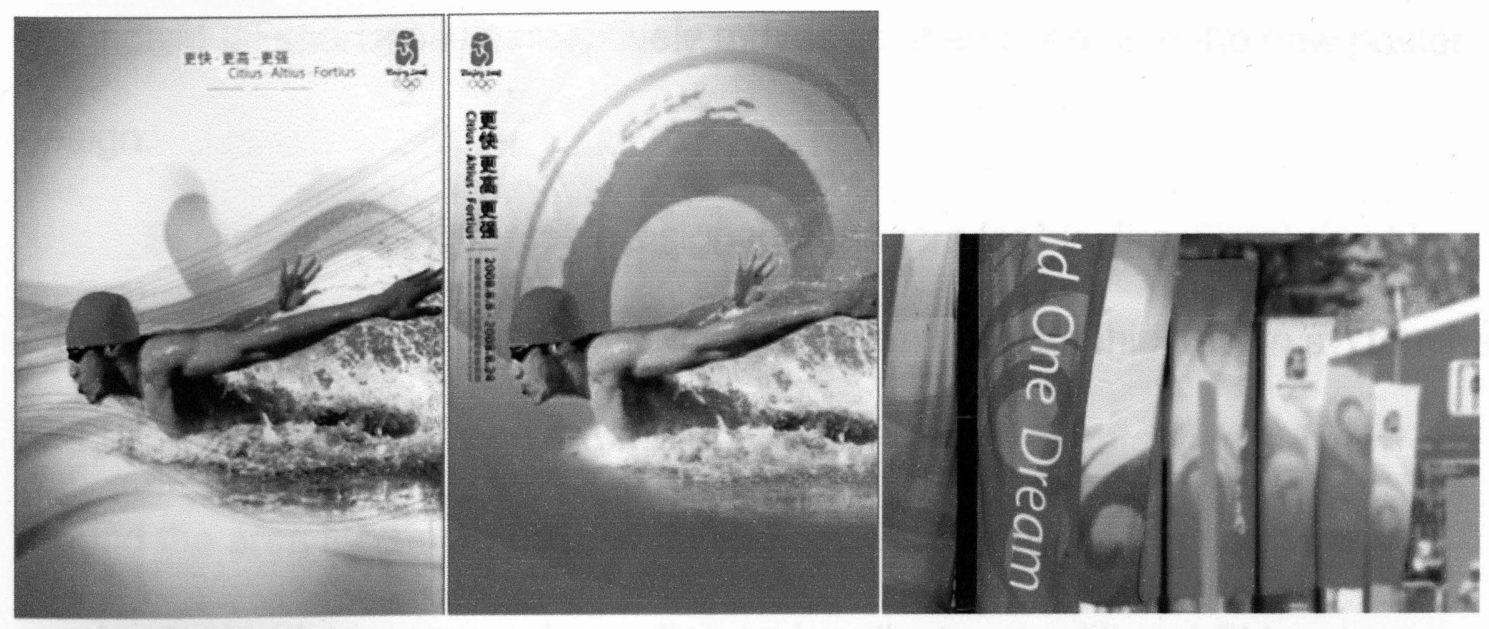

Figure 5: Swimming Event Posters and Olympic Signage Banners 
the individual sportsman perceptively moves front and center in the new poster design.

Still later, Wang creates his signage banners for his directional graphics on site of the Olympic Village. Imagine the information graphic design system he had to design to perform, so 1.8 million visitors could navigate themselves around the area for the 16 days of the events. Therefore the banners are resplendent with vigorous color coding and replicate a traditional Chinese imagery of water waves as an overall pattern. He then takes this colorful patterning, and replaces the backgrounds of his monochromatic sporting event posters. Wang has altogether replaced his first visual analogy to the original black and white sporting pictograms. He has now integrated this last wave patterned iteration of his posters, so they fit in visually with his onsite directional banners. The larger design schemata for his overall information design system, now becomes visually and conceptually integrated.

As you may now see, Wang continually worked to integrate his overall design direction together, as each new requirement was added to his workload. He continuously had to deal with each graphic element being added - in yet another medium, material, scale, placement and usage. Moreover Wang translates his Western design education, training and practice into the creation of a strategical interpretation, required of him as the head design director of the global Olympic Games. He straddles both the Western and the Eastern aesthetic sensibilities in his reiteration of the core elements of his overall design schemata. 
He uses the symbolisms and aesthetics of China, yet also invokes the rationality of the Bauhaus-derived design school.

As the Design Director of the 2008 Beijing Olympics, Min Wang has visualized Spivak's 'strategic essentialism' knowing his job was to communicate not only to his Western audience, but also to his own 1.3 billion countrymen, and importantly the Beijing Olympic Games Organizing Committee (BOGOC) and the International Olympic Committee (IOC). For sure, 'Brand China' was making her world debut as a nation, and Min Wang and his designers were fully cognizant of the importance of their design mission.

Finally in relationship to the postcolonial theories of this paper, Min Wang's design work is Spivak's iconic model of a 'subaltern object' using 'strategic essentialism' as 'speaking truth to power.' Wang managed to maintain a 'Chinese-ness' to his Olympic designs, yet tactically planned and worked as a Western trained designer would do - using the rationality of tight grid systems, strict color coding, clean typography, highly descriptive system manuals, and his personally-trained staff of designers to carry out the humongous tasks that was bestowed upon him. Min Wang's earlier notions of a global designer, which he had written about in his 2001 self-published book, Square Two World, Square Two Design: TWO WORLD DESIGN, had come to fruition:

designer's synthesis ability comes from... understanding, absorbing and grasping a myriad of social factors... multi-culture trends and diversified history [ical] backgrounds... insight to culture, art, and society, both global 
and indigenous... [a] grip on aesthetics, human relations, market and technology. ${ }^{53}$

Indeed Min Wang had actualized his philosophy through his Olympic

design work. Or as designer writer, Rajeshwari Ghose, ${ }^{n 4}$ lucidly states in her description of Asian designers' who may have conflicted sense of agency, speaking from a post-colonial perspective:

Much of the polemics concerning design... in Asia is centered on this inherent tension between the local and the global, both in the material and cultural sense. At one end of the design spectrum is those who believe ...Asian countries can and will achieve First World [Western] standards of living if only the right technological mix ... right degree of patience ... necessary amount of time ... for the trickle-down effect ....can be achieved..$^{55}$

Min Wang clearly attained Ghose's notion of the right technological mix, patience, and the posturing for his Western viewing audience, while maintaining his Eastern sensibilities as a visual showcase for the China's global debut.

\section{1) 2008 Beijing Olympics}

Designers are... playing an important role in balancing the Globalization and Nationalization, Unification and Diversification. Potentials of being able to understand the interactions between native culture and the trend of globalization rightly justify their roles to be messengers of cultural communications...The world needs a visual language to facilitate the communication and understanding among people with various

\footnotetext{
${ }^{53}$ Min Wang, Square Two World, Square Two Design: TWO WORLD DESIGN, (Publication date not available @ 2001), 6.

${ }^{54}$ Rajeshwari Ghose, "Design And Development In South And Southeast Asia: An Overview," Design and Development in South and Southeast Asia, edited by Rajeshwari Ghose. (Hong Kong: Centre of Asian Studies, University of Hong Kong), 1990, 3-16. 55 Ibid., 26.
} 
backgrounds, and this visual language can only be drawn on in-depth knowledge of diverse cultures. ${ }^{56}$

-Min Wang-

Indeed until most recently, that is after the 2008 Beijing Olympic games took place, a positive view ${ }^{57}$ on the state of modern Chinese graphic design was difficult to find in the Western trade press. Written in 2008, Ellen Shapiro of Communication Arts offered her answer, "This could be the biggest design program in history." She said:

More designers are involved, more energy, more years of work. And the largest audience. It's estimated that 4.5 billion television viewers will watch the 208 Summer Olympic Games... One million people are expected to visit China this August, including 25,000 journalists. ... The 'Beijing 2008' logo is on everything from Coke cans (see Figure 6) ${ }^{58}$ to UPS truck. Every citizen is expected to contribute, to be part of the process of bringing the People's Republic into the modern world. And that includes... using cell phones with Olympic logos and buying Olympic mascot dolls for their children. ${ }^{59}$

Thus, with her as a publication offering a Debordian view of the 2008 Olympic Games, Western graphic designers may have to alter their view of Chinese graphic designers, especially given the immense visual spectacle the 2008 Beijing Olympic images projected globally. The Games drew the largest TV viewing audience ever, an estimated 4.5 billion people, were mesmerized and astounded at the colossal skill of technology, choreography, costuming, colors,

56 Min Wang. Square Two World, Square Two Design: TWO WORLD DESIGN, (No publication date @ 2001).

${ }^{57}$ Ellen Shapiro. "Olympic Design Team: visualizing the dream of 1.3 billion people," Communication Arts, Vol. 360, (May/June 2008): 86 - 93.

${ }^{58} \mathrm{http}: / /$ media.photobucket.com/image/2008\%20Beijing\%20Olympic\%20Coke\%20Can/w cw573/CocaColaHKOlympic2008Can1-1.jpg

${ }^{59}$ Ibid., 87. 


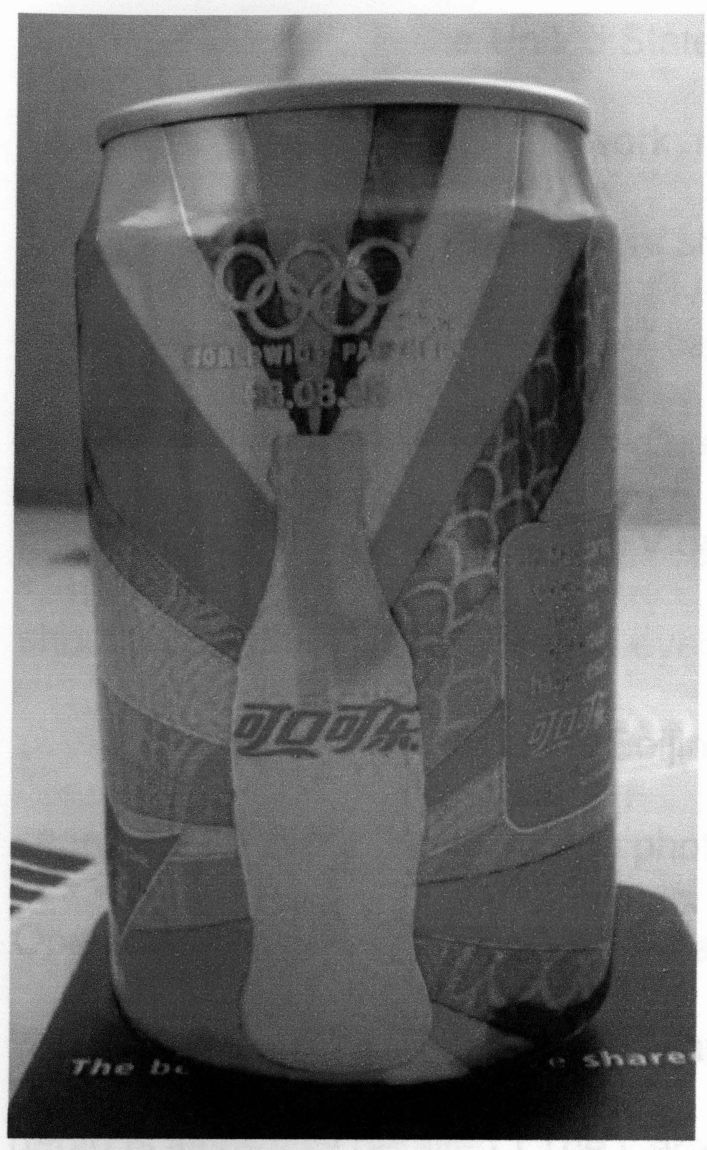

Figure 6: 2008 Olympic Coke Can 
and visual happenings of the 'New China' or perhaps more appropriately the 'Chinese Modern.' In the United States alone, NBC-TV drew around 30 million viewers a night on its main network, matched equally in number on its website, with over 6 million of Internet users sharing their videos with others and several millions more tuning into their $24 / 7$ cable channels. ${ }^{60}$ (Also Min Wang's designs had to conform to work in this medium for continuity sake. His was no small task given the number and variety of TV openings, bumpers, lower thirds, over-theshoulder graphics, statistics, and event features.)

Visiting the 'Official 2008 Beijing Olympic' website, ${ }^{61}$ even if one had not seen the live event unfolding, the photographic and video documentation of the Opening and Closing Ceremonies peaks one's interests. (By the way even the website design ${ }^{62}$ was tied into Min Wang's Olympic branding and its breadth and depth is incredibly detailed.) The Ceremonies are posted and highlighted with astounding statistics of the number of events, performers, athletes, audience, coordination and technology involved. All these facts add up to stunning visuals, almost unbelievable, because previously unseen, and so carefully documentedverbally and visually. There were many scenes, but some of the more memorable ones from the Opening Ceremony including: 2,008 drummers beating their percussive instrument at the same time, chanting a Confucius phrase that

\footnotetext{
${ }^{60}$ Bill Carter and Richard Sandomir. "A Surprise Winner at the Olympic games in Beijing: NBC." New York Times, August 17, 2008.

${ }^{61}$ http://en.beijing2008.cn/ceremonies/headlines/n214519367.shtml (accessed August 2009).

${ }^{62}$ http://en.beijing2008.cn/ (accessed August 2009).
} 
welcomes the visitors and declares how happy they are to see them come from afar. (see fig. 7) Another highlight included seeing nearly 900 people forming stadium-size Chinese characters, by moving up and down, to form the numbers of the countdown to the Opening of the Games, executed simultaneously in Chinese and English (see fig. 8). Then after the Olympic Torch was lit, across Beijing, in four major sectors of the nation's capital city, ${ }^{29}$ including the Temple of Heaven, the Forbidden City and Tiananmen Square. A seemingly never-ending firework displays (twenty-nine in all), light up the night sky to demonstrate the power and invention of China's gunpowder in 960-1276 AD. (see fig. 9). Clearly the Opening Ceremony alone was a tour de force on the world's stage, for the rising nation's global premiere.

In a Los Angeles Times newspaper article of April 2009, reporter Don Lee writes:

Some Chinese scholars say Beijing's newly assertive stance reflects the sentiments of many of its citizens who, they argue, lost their romantic illusions about the U.S. economic model and its superiority in the wake of the made-in-America recession. many people looked at the Beijing Summer Olympics as a defining moment of China's rise. It turns out that's little compared with the global financial crisis. The real Olympics is now, and the Chinese are doing much better than the competition. ${ }^{63}$

\section{Bhabha, MEWE Design Alliance and the" Third Space'}

Working to reach beyond Edward Said's dialectical notions of Orientalism (1978) and Occidentalism, as well as other postcolonialists, Homi Bhahba, counters by writing his alternative theory in his book, The Location Of Culture

${ }^{63}$ Don Lee. Los Angeles Times, April 2, 2009: 1. 


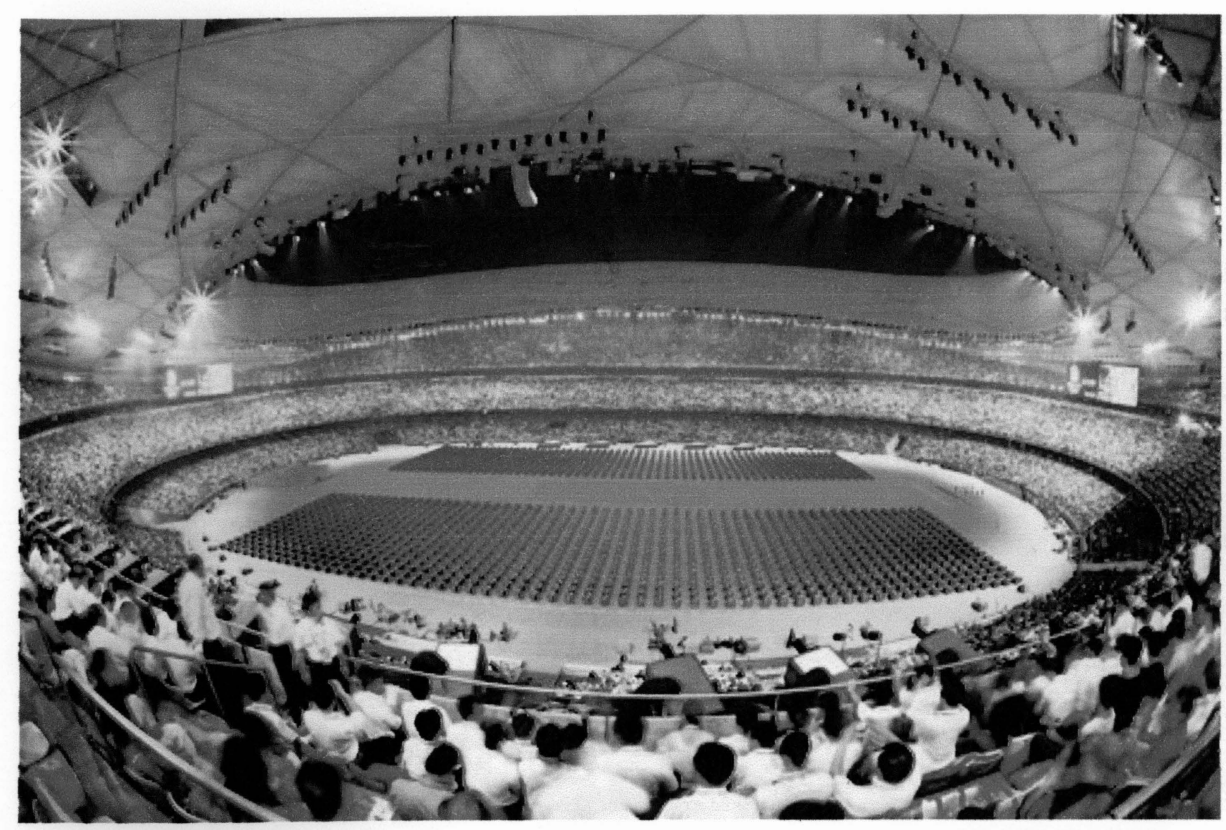

Figure 7: 2,008 Drummers in formation on stadium's floor ${ }^{1}$

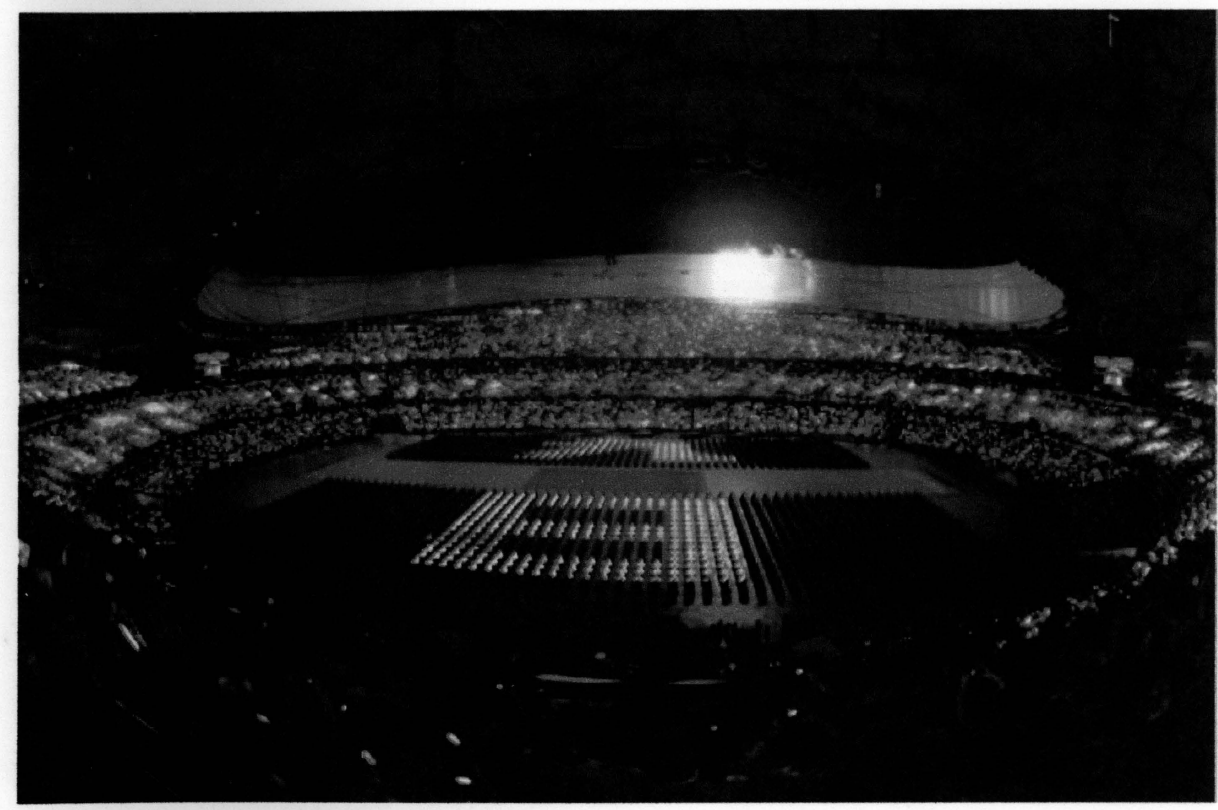

Figure 8: 900 people form the countdown numbers ${ }^{2}$

\footnotetext{
${ }^{1}$ (Photo credit: Adam Pretty/Getty Images)" http://en.beijing2008.cn/ceremonies/photos/openingceremony/performances/n21 4516417. shtml. (accessed September 2009) ${ }^{2}$ http://en.beijing2008.cn/ceremonies/headlines/n214519367.shtml (accessed September 2009)
} 


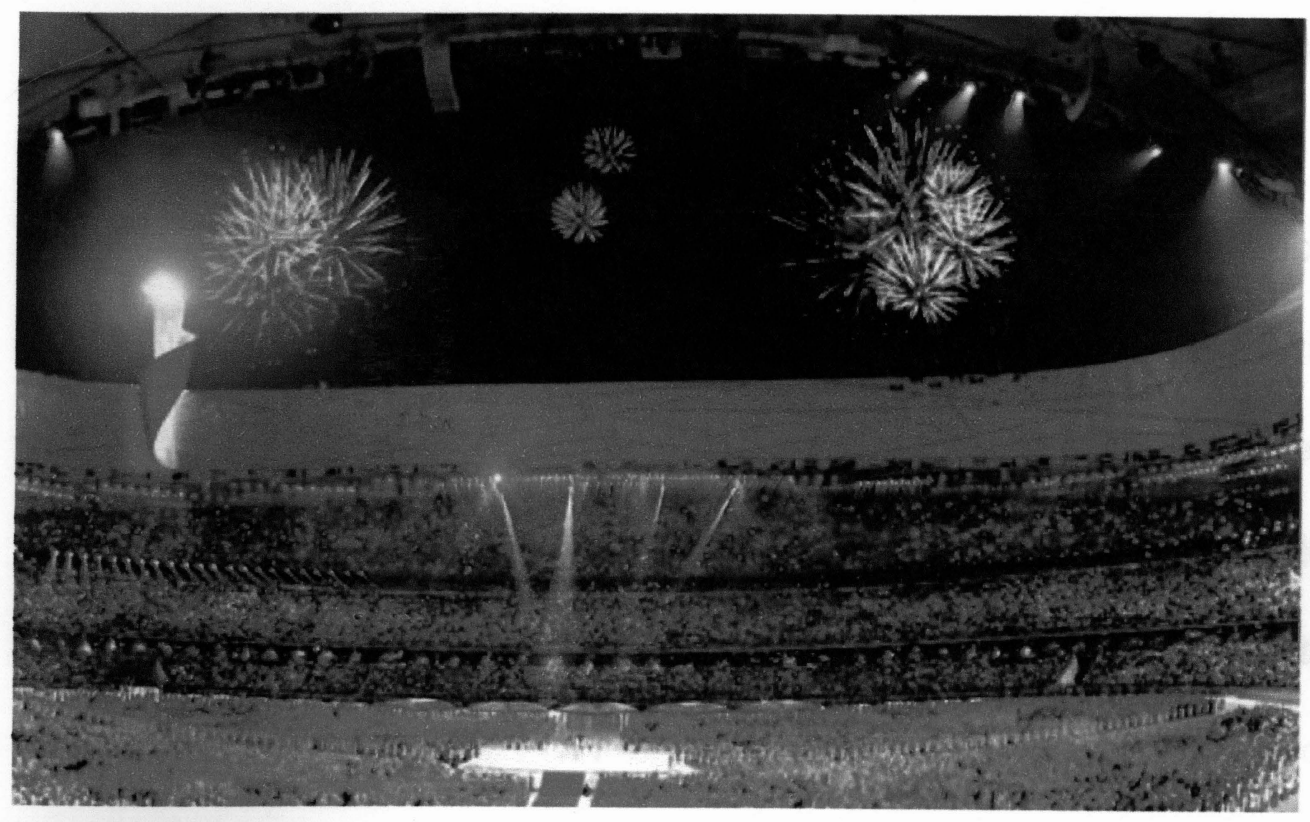

Figure 9: 29 fireworks display, in 1 of 4 areas, of the city of Beijing ${ }^{3}$

${ }^{3}$ (Photo credit: Alexander Hassenstein/Bongarts/Getty Images)" http://en.beijing2008.cn/ceremonies/headlines/n214519367.shtml (accessed September 2009) 
(2006), ${ }^{64}$ on post-colonialism, poststructuralism and culture. Bhabha points out, whereas Said's Orientalism could not exist without its relationship to Occidentalism - the colonizer to the colonized, the dominate to the sub-dominant, Bhabha prefers unlocking Said's binary oppositional stance, and allowing modernist theories to become unhinged, severing the outmoded western dynamic in a postcolonial, poststructuralist, 'post-post' world. Nonetheless, Bhabha agrees with Said's assessment of seeing history as 'performative', not metaphysical or fixed. However, Bhahba insists other narratives be added and heard in a language that is 'mulitvocal' and relevant to contemporary space and time. He urges the subaltern postcolonialists, as well as the other poststructuralists, to move to a place of 'cultural hybridity' and 'linguistic multivocality' - to disrupt and dispel the modernist tension of opposites - to allow modernity to collapse under its own burden of colonialism - to exist in the vacuum left behind or the space in-between. As Bhabha writes:

...the theoretical recognition of the split-space of enunciation may open the way to conceptualizing an international culture, based not on the exoticism or multi-culturalism of the diversity of cultures, but on the inscription and articulation of culture's hybridity. ${ }^{65}$

Furthermore, Bhabha prognosticates changes must take place and be redefined to what it means to be a human being living in our changed world today. He advises his readers to relocate their own culture into his new 'Third

\footnotetext{
${ }^{64}$ Bhabha, Homi. The Location of Culture, New York: Routledge, 1994.

${ }^{65}$ Homi K. Bhabha. "Cultural Diversity and Cultural Differences." In The Postcolonial Reader, edited by Bill Ashcroft and Gareth Griffiths, Helen Tiffin, (New York: Routledge), 1997, 207.
} 
Space' and time. Here, between the borders set of the last $20^{\text {th }}$ century of colonialism and postcolonialism, he argues rather than being trapped in either opposing view, Bhabha encourages humanity to liberate themselves out of their narrow sense of nationality, ethnicity and identity into the now vacant space in the middle. He asks people to enter into the 'Third Space' where many voices, 'multivocality', and various mixed states of being, 'hybridity,' may thrive. He writes " a vision of the future is the belief that we must not merely change the narratives of our histories, but transform our sense of what it means to live, to be, in other time and different spaces, both human and historical. ${ }^{n 6}$ By rigorously rethinking representation and resistance that has characterized the site of colonial contestation, so Bhabha believes a construction of a new 'liminal' space where cultural variations may enunciate their uniqueness, will be created and make a newly imagined and constructed sense of community. He writes:

...the in-between ...that carries the burden of the meaning of culture. It makes it possible to being envisaging national, anti-nationalist, histories of the 'people. It is in this space that we will find those words with which we can speak of Ourselves and Others. And by exploring this hybridity, the 'Third Space', we may elude the politics of polarity and emerge as the others of our selves. ${ }^{67}$

In fact, a young group of graduates from Min Wang's School of Design at CAFA have constructed such a 'liminal' graphic design studio from which to

${ }^{66}$ Excerpted from Rob Wilson and Wimal Dissanayake, Global/Local: Cultural Production and the Transnational Imaginary, (Durham, NC: Duke University Press), 1996, 1-14.

${ }^{67}$ Homi K. Bhabha. "Cultural Diversity and Cultural Differences," in The Postcolonial Reader, edited by Bill Ashcroft and Gareth Griffiths, Helen Tiffin, 206-209, New York: Routledge, 1997, 209. 
operate in a hybrid and multivocal manner. Called MEWE Design Alliance, ${ }^{68}$ the students' work was featured in the V \& A's "China Design Now" show in 2008. When I visited Beijing in 2004 at the AGI annual conference, I had an opportunity to interview three of the MEWE designers - Liu Zhizhi (b. 1975), He Jun (b. 1977), and Yu Guang (b. 1977) ${ }^{69}$ All three were dressed in the most current, hiphop style of global youth culture. When I asked through a translator about the works of the designers they most admired, they named the countries whose design they most admired - Japan, Germany, Holland and England. These young men answered my questions, without hesitation and very directly. When I asked them what they thought about the state of design in China, they eagerly answered me, even overlapping one another, sometimes speaking at the same time:

They are way ahead of the game compared to us. Taiwan designers put more traditional elements into their work, so visually the work ends up looking more Chinese. Hong Kong designers have a style more like the Western designers, but they keep some of the Chinese sensibilities. Their work looks like it's undergoing a transitional change from Eastern to Western design. Taiwan designers use traditional Chinese elements more accurately and profoundly than the Mainland or Hong Kong designers. Currently, we, Mainland designers, choose to follow the Western design more.

When I asked them what they thought of their future as designers, they gleefully answered, "There is a bright future in design. [People] consume design as they do other products." When I tried to push them further in articulating what

\footnotetext{
${ }^{68} \mathrm{http}: / / w w w . v i 11$ age.com/article/29/mewe_design_alliance. http://www.meweda.com/ (accessed September 4, 2009)

${ }^{69}$ Catherine Jo Ishino, "Seeing Is Believing: Reflections on Video Oral Histories with Chinese," 326-327, Journal of Design History 19, no. 4 (2006), 319-331.
} 
they meant by their statement, and asked them, "How would you describe the state of PRC design?" Their replies were, "We have confidence in ourselves. We can make it better." Lastly, I asked them, "What advice would you give to other designers [coming onto the scene]?" They answered very quietly and seriously, "First have confidence in [one's] self. Gain techniques in a short period [of time]. Never give up; just keep doing it! Yeah!!!" 70

The designers of MEWE were already steeped in post-post modernism and stood certain in wanting to work with, but not necessarily learn from, the Western designers. In visually analyzing one of the young designer's work at the in the group, He Jun's design (see figure 4) has indeed gained technique and his confidence. His ability is now clear in his work that was featured in the Victoria \& Albert Museum's catalog for its "China Now Design" exhibition. ${ }^{71}$ The buoyant and ebullient energy of his imagery is palpable on this full title page in the book. He displays a reverie of action, against the plain white background (no longer alluding to the funerary use of the color in Asian culture as Xu Wang did earlier in his Nagasaki and Hiroshima bombing posters), but more using the hue in a neutral and abstracted manner and as it might be utilized in Western graphic design. In the foreground of his layout, Hun shows us a multiplicity of small, white, light and numbered lottery balls, being spun out of a whirring mechanism that propels them - towards, away, and in front of the viewer. The viewer's eyes follow the action of the moving balls, seeming to be bouncing all out of control.

\footnotetext{
${ }^{70}$ Ibid., 327.

${ }^{71}$ He Jun, in "Shenzen: Frontier City," in China Design Now, 34-35, edited by Zhang Hongxing and Lauren Parker, (London: V\&A Publications), 2008.
} 


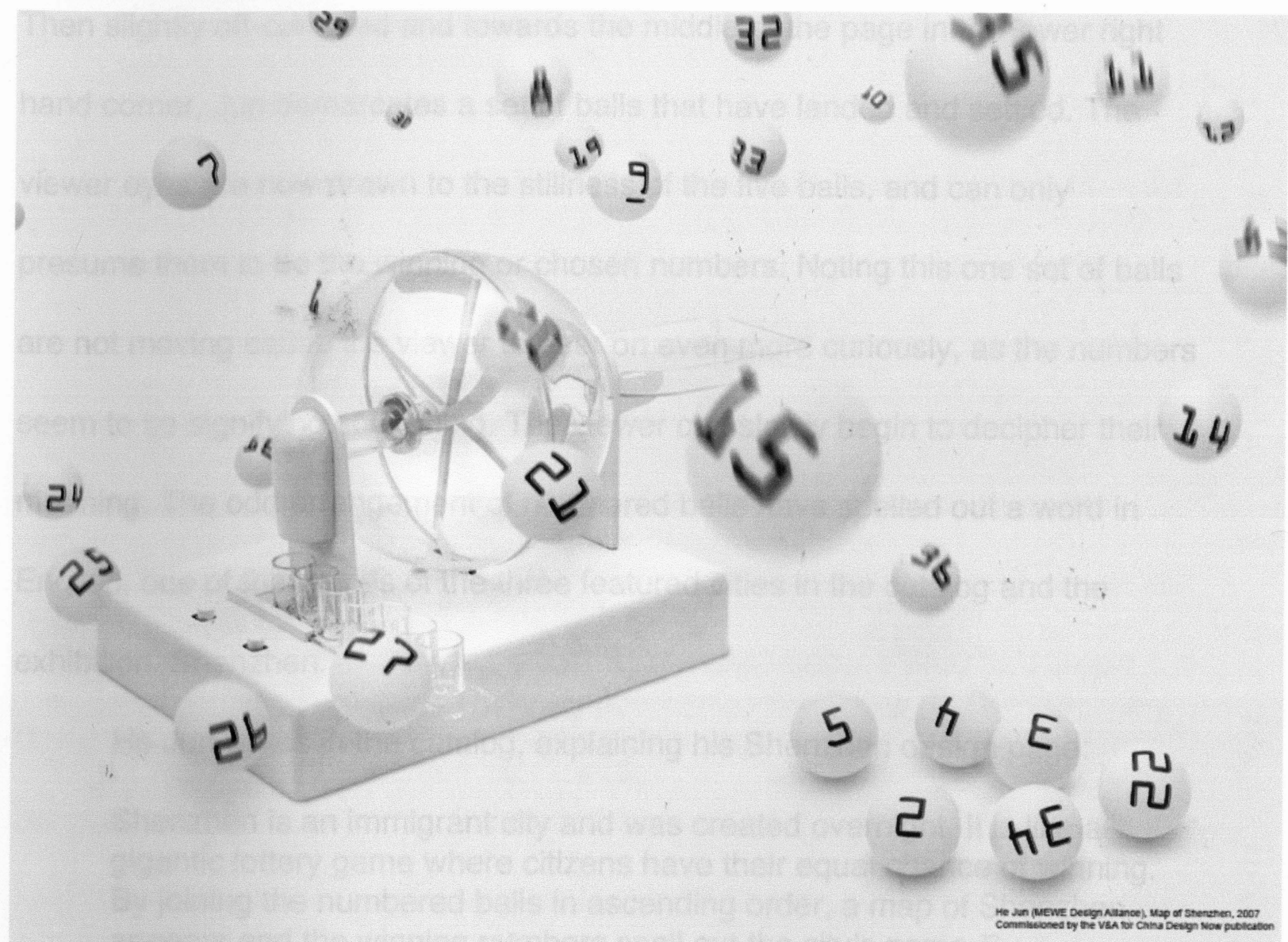

Fig. 10 MEWE's design example by He Jun 
Then slightly off-centered and towards the middle of the page in the lower right hand corner, Jun demarcates a set of balls that have landed and settled. The viewer eyes are now drawn to the stillness of the five balls, and can only presume them to be the winning or chosen numbers. Noting this one set of balls are not moving cause the viewer to peer on even more curiously, as the numbers seem to be signifying something. The viewer can slowly begin to decipher their meaning. The odd arrangement of numbered balls have spelled out a word in English, one of the names of the three featured cities in the catalog and the exhibition, Shenzhen.

He Jun writes in the catalog, explaining his Shenzhen design page:

Shenzhen is an immigrant city and was created overnight. It is like a gigantic lottery game where citizens have their equal chance of winning. By joining the numbered balls in ascending order, a map of Shenzhen appears and the winning numbers spell out the city's name. ${ }^{72}$

Clearly the latter's visual voice is beginning to be heard, as well as $30-$ something Chinese designers such those in the MEWE Design Alliance. They as well as other young designers, are beginning to be heard in the larger globalization design narrative, and enriching visual texts worldwide. They are ably and confidently creating in Bhabha's 'Third Space' of 'multivocalism' and 'hybridity.'

\section{CONCLUSION}

vision is... a 'cultural construction' that it is learned and cultivated, not simply given by nature. ... with the history of arts, technologies, media, and social practices of display and spectatorship... it is deeply involved with

72 Ibid., 34. 
human societies, with ethics and politics, aesthetics and epistemology of seeing and being seen. ${ }^{73}$

- WJT Mitchell -

Clearly we, in the West and East, have been left reeling, not only from the seeing the Olympic spectacle, but also perhaps even more crucially from the current economic crisis. I believe the 'Chinese Modern' graphic design goal of combining and understanding how to forefront and manipulate their own cultural visual language has begun to materialize. The current designs, such as the MEWE Design Alliance's works, reach beyond Said's Orient/Occident binary, or Spivak's 'essentialized strategy," or perhaps moved beyond Bhabha's utopic 'Third Space,' to exist in a space uniquely their own as fully-fledged members of the global design community. Still one is left to wonder, with all of the world-wide heightened economic frenzy and push for modernization, will the next generation of Chinese designers be allowed to continue to create in their bricollaged visual language? Will they be forced to succumb to the voraciousness of our allconsuming globalized society? Or will these designers face a restraining curtailment of their current expressive freedom and practice from their government? Anyway one looks at their global outlook today, the next generation of Chinese graphic designers have had a pathway cut wide and deep by their predecessors, who have begun pointing them on their way into the $21^{\text {st }}$ century.

\footnotetext{
${ }^{73}$ WJT Mitchell, "Showing Seeing: A Critique Of Visual Culture," 166, Journal of Visual Culture, Vol. 1, No. 2, (2002): 165-181.
} 


\section{BIBLIOGRAPHY}

Anderson, Chris. "Wang Xu: Graphic design's evangelist in China." Graphis 316 (1998): 22-31.

Aldersey-Williams, Hugh. World design: Nationalism and Globalism in Design. New York: Rizzoli, 1992.

Aynsley, J. Nationalism and Internationalism: Design in the $20^{\text {th }}$ Century. London: Victoria \& Albert Museum, 1993.

Banham, Reyner. Design by Choice, edited by Penny Sparke. New York: Rizzoli, 1981.

Barnard, Malcolm. Art, Design, and Visual Culture: An Introduction. New York: St. Martin's Press, 1998.

Berger, John. Ways of Seeing. London: British Broadcasting Corporation / Harmondsworth: Penguin, 1972.

Bhabha, Homi K. "Cultural Diversity and Cultural Differences." In The Postcolonial Reader, edited by Bill Ashcroft, Gareth Griffiths, and Helen Tiffin, 206-212. New York: Routledge, 1997.

Bhabha, Homi K. The Location of Culture, New York: Routledge, 1994.

Bové, Paul A. "'Global/Local' Memory and Thought." In Global/Local, edited by Wilson, Rob and Wimal Dissanayake, 372-386. Durham: Duke University Press, 1996.

Brennan, Timothy. "The National Longing for Form." In The Postcolonial Reader, edited by Bill Ashcroft and Gareth Griffiths, Helen Tiffin, 170-175. New York: Routledge, 1997.

Caban, Geoffrey. World Graphic Design: Contemporary Graphics from Africa, the Far East, Latin America and the Middle East. New York: Merrell, 2004.

Chatterjee, Partha. "Whose Imagined Communities?" In Internationalizing Cultural Studies: An Anthology, edited by Ackbar Abbas and John Nguyet Erini, 406-412. London: Blackwell Publishing, 2005.

Clark, Helen. Introduction to Design Issues 19, no. 3 (Summer 2003): 1-3. 
Coombe, Rosemary J. "Is There Legal Protection for Cultural Imagery?" In Design Culture, edited by Steve Heller and Marie Finamore, 16-18. New York: Alworth Press, 1997.

Dayal-Gulati, Anuradha and Angela Y. Lee, eds. In Kellogg on China : Strategies for Success, edited by, Evanston, IL : Northwestern University Press, 2004.

Dallmayr, Fred R. Beyond Orientalism: Essays on Cross-Cultural Encounter. Albany, NY: State University of New York Press, 1996.

Dilnot, Clive. "Which Way Will the Dragon Turn? Three Scenarios for Design in China over the Next Half-Century." In Design Issues 19, no. 3 (Summer 2003): 5-20.

Ding, E. "Saussure, Peirce, and the Chinese Picto-phonetic Sign." The American Journal of Semiotics 23, no. 14, (January 1): 67-79, 375.

Dirik, Arif. "The Global in the Local." In Global/Local, edited by Rob Wilson and Wimal Dissanayake, 21-45. Durham, NC: Duke University Press, 1996.

Doordan, Dennis, John Heskett, and Victor Margolin. "Introduction." In Design Issues 6, no. 1 (Autumn 1989): 2-3.

Featherstone, Mike. "Localism, Globalism, and Cultural Identity." In Global/Local, edited by Wilson, Rob and Wimal Dissanayake, 46-77. Durham, NC: Duke University Press, 1996.

Fenollosa, Ernest Francisco. Epochs of Chinese and Japanese Art: An Outline History of East Asiatic design. New York: Dover Publications, 1963.

Ghazoul, Ferial J. "Orientalism: Clearing the Way for Cultural Dialogue." Religion 34, no.2 (April 2004): 123.

Ghose, Rajeshwari. "Design and development in South and Southeast Asia: An overview." In Design and Development in South and Southeast Asia, edited by Rajeshwari Ghose, 3-16. Hong Kong: Centre of Asian Studies, University of Hong Kong, 1990.

Hayford, Elizabeth. "Culture and Imperialism by Edward W. Said." Edward Said: A Critical Reader, edited by Michael Sprinker. Library Journal 118, no. 4 (March 1993): 94. 
Hall, Stuart. "Racist Ideologies and the Media." In Media Studies: A Reader, edited by Paul Marris and Sue Thornham, 271-281. New York: New York University Press, 2006.

Hall, Stuart. Representation: Cultural Representations and Signifying Practices, edited by Stuart Hall. London: Sage, 1997.

Hall, Stuart and Paul du Gay, eds. Questions of Cultural Identity. Thousand Oaks, CA: Sage, 1996.

Hall, Stuart, Sut Jhally and the Media Education Foundation, eds. Race: The Floating Signifier. Classroom edition. Northampton, MA: Media Education Foundation, 1996.

Hall, Stuart and Dorothy Hobson, Andrew Lowe, and Paul Willis, eds. Culture, Media, Language: Working Papers in Cultural Studies, 1972-79. New York: Routledge, 1980.

Heller, Scott. "After 'Orientalism': Exploring the Complicity of Literature and Empire." The Chronicle of Higher Education 39, no. 37 (May 19, 1993): A7.

Hirschkop, Ken. "Introduction: Bakhtin and Cultural Theory." In Bakhtin and Cultural Theory, edited by Ken Hirschkop and David Shepherd, 1-38. Manchester: Manchester UP, 1989.

Hofstede, Geert Hendrik. Culture's Consequences: Comparing Values, Behaviors, Institutions, and Organizations Across Nations. 2nd ed. Thousand Oaks, CA: Sage Publications, 2004.

Hongxing, Zhang and Lauren Parker, eds. China Design Now. London: V\&A Publications, 2008.

Ishino, Catherine Jo. "Seeing Is Believing: Reflections on Video Oral Histories with Chinese." Journal of Design History 19, no. 4 (2006): 319-331.

Ilyin, Natalia. "Fabulous Us: Speaking the Language of Exclusion." In Design Culture, edited by Steve Heller and Marie Finamore, 116-118. New York: Alworth Press, 1997.

Irwin, Robert. "Outsider Insights." Times Literary Supplement, December 14, 2001, 24.

JanMohamed, Abdul R. and David Lloyd. "Preface" and "Introduction: Toward a Theory of Minority Discourse: What Is To Be Done?" In The Nature and 
Context of Minority-Discourse, edited by Abdul R. JanMohamed and David Lloyd, ix-xi, 1-16. New York: Oxford University Press, 1990.

Sparke, Penny and Paola Antonelli, eds. Japanese Design. New York, NY: Museum of Modern Art, 2009.

Jarvie, Grant. Sport, Revolution and the Beijing Olympics. Edited by Dong-Jhy Hwang, Mel Brennan. English ed. New York: Berg, 2008.

Jenks, Chris, ed. In Visual Culture, ed. London: Routledge, 1995.

Julier, Guy. The Culture of Design. London: SAGE, 2000.

Kerr, Rose. Chinese Art and Design: Art Objects in Ritual and Daily Life. Woodstock, NY: Overook Press, 1997.

Kress, Gunther R. and Theo van Leeuwen. Reading Images: The Grammar of Visual Design. 2nd ed. London: Routledge, 2006.

Krippendorf, Klaus. The Semantic Turn; $A$ New Foundation for Design. Boca Ratan, FL: CRC Press, 2006.

Leong, B. D. "Culture-based Knowledge Towards a New Design Thinking." In Design Issues, 19, no. 3 (Summer 2003): 48-58.

Lipton, Ronnie. "Multicultural Design." Designing Across Cultures. Cincinnati, OH: HOW Design Books, 2002: 178 - 183.

Loomba, Ania. Colonialism - Postcolonialism. New York: Routledge, 1998.

Margolin, Victor. Review of "Chinese Graphic Design in the $20^{\text {th }}$ Century." In Design Issues, 8, no. 2 (Spring, 1992): 82-84.

McLuhan, Marshall. Essential McLuhan, edited by Eric McLuhan and Frank Zingrone. London: Routledge, 1997.

McLuhan, Marshall. Media Research: Technology, Art, Communication. Edited by Michel A. Moos. Australia: G\&B Arts, 1997.

McLuhan, Marshall. The Global Village: Transformations in World Life and Media in the 21st Century. Edited by Bruce R. Powers. New York: Oxford University Press, 1989. 
Meggs, Philip B. "Is a Design History Canon Really Dangerous?" In Design Culture, edited by Steve Heller and Marie Finamore, 228-232. New York: Alworth Press, 1997.

Miller, Anistatia R., Jared M. Brown, and Cheryl Dangel Cullen. Global Graphics, Symbols: Designing with Symbols for an International Market. Gloucester, MA: Rockport Publishers, 2000.

Mitchell, Timothy. "Orientalism and the Exhibitionary Order." In Visual Culture Reader, edited by Nicholas Mirzoeff, 293-303. York: Routledge, 1998.

Mitchell, W.J.T. "Edward Said: 'Continuing the Conversation.' Critical Inquiry 31, no. 2 (Winter 2005): 365- 370.

Mitchell, W.J.T. Iconology: Image, Text, Ideology. Chicago: University of Chicago Press, 1986.

Mitchell, W.J.T. "Postcolonial Culture, Postimperial Criticism." In The Postcolonial Reader, edited by Bill Ashcroft and Gareth Griffiths, Helen Tiffin, 475-479. New York: Routledge, 1997.

Mitchell, W.J.T. What Do Pictures Want? The Lives and Loves of Images. Chicago: University of Chicago Press, 2005.

Minick, Scott and Jiao Ping. Chinese Graphic Design in the Twentieth Century. London: Thames and Hudson, 1990.

Morley, David. "Cultural Transformations: the Politics of Resistance." Edited by Paul Marris and Sue Thornham, 471- 481. Media Studies: A Reader. New York: New York University Press, 2006.

Mulvey, Laura. Visual and Other Pleasures. London: Macmillan, 1989.

National Instructive Committee of Industrial Design Education, China, 2004. 9accessed December 20, 2004). http://edu.dolcn.com/schoolist.html.

Neumeier, Marty. The Brand Gap: How to Bridge the Distance Between Business Strategy and Design: A Whiteboard Overview. Rev. ed. Berkeley, CA: New Riders, 2006.

Price, Monroe Edwin and Daniel Dayan, eds. Owning the Olympics: Narratives of the new China. Ann Arbor, MI: Digitalculturebooks, 2008. 
Peterson, L. K. and Cheryl Dangel Cullen. Global Graphics: Color, A Guide to Design with Color for an International Market. Gloucester, MA: Routledge, 2000.

Morton, Stephen. Gayatri Chakravorty Spivak. New York: Routledge, 2003.

Roche, Maurice. Mega-Events and Modernity: Olympics and Expos in the Growth of Global Culture. London: Routledge, 2000.

Poyner, Rick. Design Without Boundaries: Visual Communications in Transition. London: Booth-Clibborn Editions, 1998.

Poyner, Rick. Review of "Get It Louder" graphic design show in the New China, Design Observer, May 5, 2005. http://www.designobserver.com/archives/002505.html (accessed August 2006).

Pratt, M. L. Imperial Eyes: Travel Writing and Transculturation. New York: Routledge. 1992.

Peters, Robert L. "No Sleeping Dragon." Communication Arts, March/April 2004.

Radhakrishnan, R. "Ethnic Identity and Post-Structuralist Difference." In The Nature and Context of Minority Discourse, edited by Abdul R. JanMohamed and David Lloyd, 50-71. New York: Oxford University Press, 1990.

Robins, Kevin. Into the Image: Culture and Politics in the Field of Vision. New York: Routledge, 1996.

Rose, Gillian. Visual Methodologies. Thousand Oaks: Sage Publications, 2005.

Rowe, David, ed. Critical Readings: Sport, Culture and the Media. Maidenhead, Berkshire: Open University Press, 2004.

Ruffins, Faith Davis. "The Politics of Cultural Ownership." In Design Culture, edited by Steve Heller and Marie Finamore, 5-7. New York: Alworth Press, 1997.

Said, Edward. "Envoy to Two Cultures." New York Times, June 21, 1993, 60.

Said, Edward. "Orientalism." In The Postcolonial Reader, edited by Bill Ashcroft and Gareth Griffiths, Helen Tiffin, 87-91. New York: Routledge, 1997.

Said, Edward. "The Paradoxes of Identity." Journal of Commonwealth Literature 37, no. 1 (2002): 167. 
Said, Edward. Orientalism, New York: Vintage Press, 1978.

Said, Edward. "The Secret Sharers-Culture and Imperialism." The Village Voice 38 , no. 23 (Jun 8): SS31.

Said, Edward and David Barsamian. Culture and Resistance: Conversations with Edward Said. Cambridge, MA: South End Press, 2003.

Scotford, Martha. "Is There a Canon of Graphic Design History?" In Design Culture, edited by Steve Heller and Marie Finamore, 218-227. New York: Alworth Press, 1997.

Shohat, Ella. "Area Studies, Transnationalism, and the Feminist Production of Knowledge." Signs 26, no. 4 (Summer 2001): 1269.

Shohat, Ella. "Gender and Culture of Empire: Toward a Feminist Ethnography of the Cinema." Quarterly Review of Film and Video 13, no. 1-3 (May 1991): 45.

Shohat, Ella and Robert Stam. "From the Imperial Family to the Transnational Imaginary: Media Spectatorship in the Age of Globalization." In Global/Local, edited by Rob Wilson and Wimal Dissanayake, 145-172. Durham, NC: Duke University Press, 1996.

Shohat, Ella and Robert Stam. "Narratizing Visual Culture: Towards a Polycentric Aesthetics." In The Visual Culture Reader, edited by Nicholas Mirzoeff, 2752. New York: Routledge, 1998.

Shohat, Ella. "Unthinking Eurocentrism: Multiculturalism \& the Media." Review. Canadian Literature 151 (Winter 1996): 199-201.

Siomopoulos, Anna. "What W. J. T. Mitchell Wants." Review of What Do Pictures Want? The Lives and Loves of Images, "by W.J.T. Mitchell, afterimage, January/February 2006.

Sparke, Penny. A Century of Design: Design Pioneers of the $20^{\text {th }}$ Century.

London: Mitchell Beazley, 1998.

Sparke, Penny. Design in Context. London: Bloomsbury, 1987.

Spivak, Gayatri C. "Poststructuralism, Marginality, Postcoloniality and Value." In Literary Theory Today, edited by Peter Collier and Helga Geyer-Ryan, pp. 219-244. Cambridge: Polity Press, 1990. 
Spivak, Gayatri C. "Can the Subaltern Speak?" In The Postcolonial Reader, edited by Bill Ashcroft, Gareth Griffiths, and Helen Tiffin, pp. 24-25. New York: Routledge, 1997.

Spivak, Gayatri C. A Critique of Postcolonial Reason: Toward a History of the Vanishing Present. Cambridge, MA: Harvard University Press, 1999.

Spivak, Gayatri C. In Other Worlds: Essays in Cultural Politics. New York: Routledge, 1988.

Stam, Robert, and Ella Shohat. "Variations on an Anti-American Theme." CR: The New Centennial Review 5, no.1 (Spring 2005): 141.

Steiner, Henry and Hass, Ken. Cross-Cultural Design: Communicating in the Global Marketplace. London: Thames and Hudson, 1995.

Sturken, Marita and Lisa Cartwright. Practices of Looking: An Introduction to Visual Culture. Oxford: Oxford University Press, 2003.

Suderman, Jane. Understanding Intercultural Communication. Toronto: Thomson/Nelson, 2007.

Turner, Matthew. "The Future of Asian Design: 'Cultural Identity' or 'Internationalisation,"' edited by Yin Qingshan, Chen Hanqing, and Tao Jingyang, 16-21. Design and Times: Essays of the First Industry Design Meeting in China. Beijing: China Building Material Publishing, 1993.

Walker, John A and Sarah Chaplin. Visual Culture: An Introduction. Manchester, UK: Manchester University Press, 1997.

Wang, Jing. Brand New China: Advertising, Media, and Commercial Culture. Cambridge, MA: Harvard University Press, 2008.

Wang, Min. Square Two World, Square Two Design: TWO WORLD DESIGN. (No publication date @ 2001)

Wang, Min and Xiao Shen Hong. "After Mao: Chinese Graphic Design Today." Print 48.no. 3 (May-June 1994): 64- 68.

Wang, Shouzhi. "Chinese Modern Design: A Retrospective." In Design Issues, Vol. 6, No. 1, Design in Asia and Australia (Autumn, 1989), pp. 49-78

Worden, Minky. China's Great Leap: The Beijing Games and Olympian Human Rights Challenges. 1st edition. New York: Seven Stories Press, 2008. 
Williams, Raymond. "Mass Communications and Minority Culture." In Media Studies: A Reader, edited by Paul Marris and Sue Thornham, 44-50. New York: New York University Press, 2006.

Wilson, Rob. "Goodbye Paradise: Globalism/Localism in the American Pacific." In Global/Local, edited by Rob Wilson and Wimal Dissanayake, 312-336.

Durham, NC: Duke University Press, 1996.

Wilson, Rob and Wimal Dissanayake. "Tracking the Global/Local." In Global/Local. Durham, NC: Duke University Press, 1996.

Wong, Wendy S. "Detachment and Unification: A Chinese Graphic Design History in Greater China since 1979". Design Issues 17, no.4 (2001): 51-71. Paper also given at The 6th International Conference of the European Academy of Design. University of the Arts, Bremen, Germany. March 2005.

Wong, Wendy S. "In Search of a New Graphic Design Frontier in China: Establishing the 'Chinese-ness' of International Style" Journal of the Asian Design International Conference, Vol. 1: The 6th Asian Design International Conference Proceedings (CD-ROM), (accessed August 2008). http://www.ipo.tue.nl/homepages/mrauterb/conferences/CD_doNotOpen/AD C/final_paper/081.pdf

Wong, Wendy S. "Torn between Tradition and Modernity: The Future of Design Education Directions of China." International Conference on Design Education: Tradition and Modernity. National Institute of Design (NID), Ahmedabad, India, March 2005. (accessed June 2007). http://yorku.ca/wsywong/homepage/articlespdf/proceedings/wwnidfullpaper $\% 5$ Bfinal\%5D.pdf)

Zhang, J and J Liu, M Li, J Pan, J Han, L Tuo, B Sun. The Design and Implementation Of A Concept Prototype For Beijing 2008 Olympic Games. http://hccl.ioa.ac.cn/publications/zhang.pdf (accessed August 2008) 